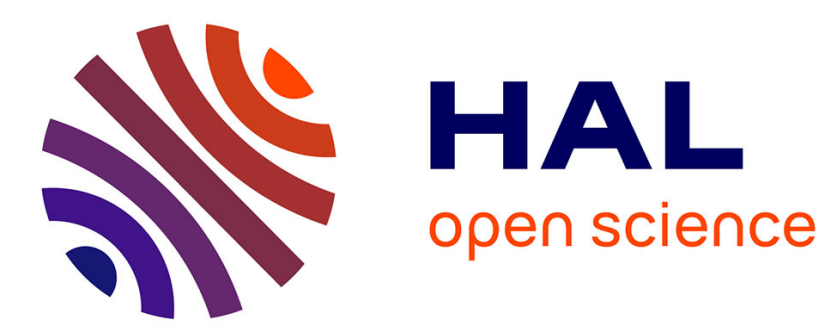

\title{
Convergence of bank competition in Central and Eastern European countries: Does ownership matter?
}

Ion Lapteacru

\section{To cite this version:}

Ion Lapteacru. Convergence of bank competition in Central and Eastern European countries: Does ownership matter?. 2016. hal-01301853

\section{HAL Id: hal-01301853 \\ https://hal.science/hal-01301853}

Preprint submitted on 13 Apr 2016

HAL is a multi-disciplinary open access archive for the deposit and dissemination of scientific research documents, whether they are published or not. The documents may come from teaching and research institutions in France or abroad, or from public or private research centers.
L'archive ouverte pluridisciplinaire HAL, est destinée au dépôt et à la diffusion de documents scientifiques de niveau recherche, publiés ou non, émanant des établissements d'enseignement et de recherche français ou étrangers, des laboratoires publics ou privés. 


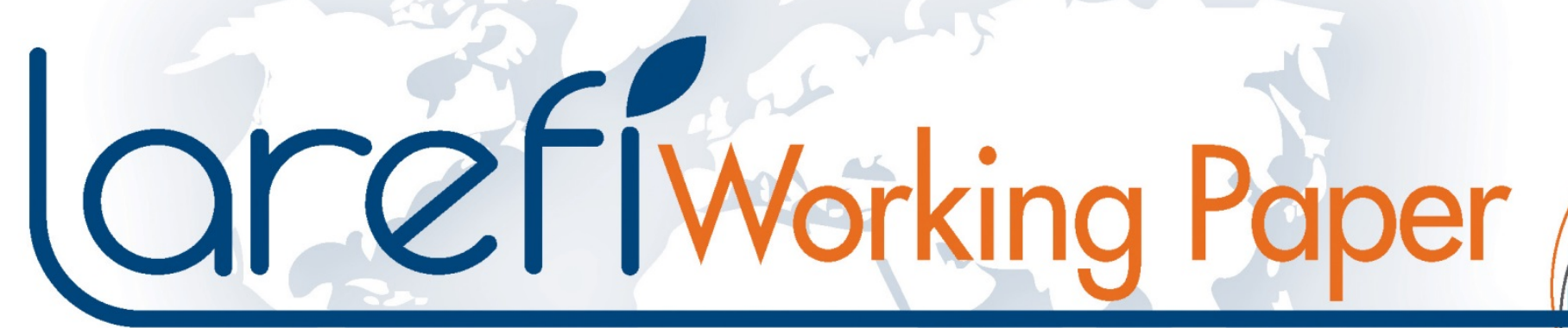

LABORATOIRE D'ANALYSE ET DE RECHERCHE En ÉCONOMIE ET FInANCE INTERnATIONALES

\section{Convergence of bank competition in Central and Eastern European countries: Does ownership matter?}

Ion Lapteacru

\section{LAREFI Working Paper N²016-06}

http://lare-efi.u-bordeaux4.fr

LAREFI

Université de Bordeaux

Bâtiment Recherche Economie $-1^{\text {er }}$ étage

Avenue Léon Duguit - 33608 Pessac 


\section{AUTHORS}

Ion Lapteacru, Larefi, Université de Bordeaux

\section{NOTICES}

LAREFI Working Papers contain preliminary material and research results. They have been peer reviewed. They are circulated in order to stimulate discussion and critical comment; any opinions expressed are only those of the author(s).

Copyright LAREFI. All rights reserved. Sections of this material may be reproduced for personal and not-forprofit use without the express written permission of but with acknowledgment to LAREFI. To reproduce the material contained herein for profit or commercial use requires express written permission. To obtain permission, contact LAREFI at cyril.mesmer@u-bordeaux.fr. 


\begin{abstract}
Many reforms of banking market liberalization in CEE countries raised the question on the convergence of banks' competitive behaviour, particularly because of the presence of foreign banks from same European regions. We find within-country convergence of three used bank competition measures, with higher convergence levels of market power and of competitive behaviour, and with faster convergence trend for foreign banks. Despite the efforts for banking market integration, there is no general movement toward across-countries convergence of competitive behaviour of CEE banks, neither for foreign nor for domestic institutions, higher dispersion of countries being however observed for the former.
\end{abstract}

JEL classification: G21, D4.

Keywords: Banking, competition, convergence, Central and Eastern European countries. 


\section{Introduction}

Governments in Central and Eastern European (CEE) countries succeeded in establishing of a competitive banking environment (Bonin et al. 2015), in opening their banking markets to foreign participation and the integration of these markets to the European banking market. Among many other competitive-enhancing regulation measures, they had to adopt the principle of home country control for banks and the principle of single banking licence that authorizes any bank of any EU state to provide banking services in another EU member without additional authorization. The latter aims particularly to favour the EU cross-border expansion of banking products and thus to increase the bank competition. Consequently, the intention of all competitive-enhancing measures to create a single EU banking market should favour a homogeneous competitive environment for CEE banks and should lead to the convergence of bank competition.

At the beginning of the transition, foreign banks were eager to enter CEE markets. As members of same large European banking groups, they proposed similar products across all CEE banking markets, some being very innovative and other more efficient. Their relative advantage in terms of expertise, technology and know-how for credit screening and risk management, as well as the reputation of their parents, might have reduced the price of their products in order to enter these markets (De Haas and Van Lelyveld, 2006; Claeys and Hainz, 2014), spreading the pressures of competition on domestic banks as well and contributing to the convergence of competition in banking. However, the same factors might have increased the price once these markets have been conquered.

The main objective of this paper is thus to investigate the integration of CEE banking markets in terms of the convergence of bank competition. A perfect banking integration implies convergence toward the same price behaviour, which might be expected at least for foreign banks. However, different regulatory environments, various entry policies into these banking markets and different privatisation procedures of state-owned banks, among many other factors, would hamper foreign banks in CEE countries to behave alike.

No study, to the best of our knowledge, explored this important issue on CEE banks. Few papers on the subject focusing on the EU-15 banking markets emphasize different levels of European banks' competitiveness, in spite of a global increase in competition among these institutions (De Bandt and Davis, 2000). Molyneux et al. (1994) have firstly mentioned that these different competition levels are sign of lack of integration of European banks.

Our intention is thus, firstly, to assess the bank competition and its evolution in CEE economies and to examine if there is a difference between foreign and domestic banks. Our findings will contribute to a better understanding of the role of many competition-enhancing measures, as opening of the banking market and the entry of new banks, as well as competition-reducing measures, as merger-and-acquisition wave in these banking industries. A divergent competitive behaviour between foreign and domestic banks may hamper the homogenization process on CEE banking markets, which hastened after EU accession. Secondly, we aim to study whether there is convergence in bank competition both within and across CEE banking industries. This issue is of a great importance at least for the following three reasons. First, the within-country convergence is, as mentioned, a sign of harmonization in banking industry: domestic banks performs more and more new activities introduced by foreign counterparts, such as underwriting and trading securities, brokerage and investment, and therefore approach closer to practices of foreign banks. This might imply lower prices for banking products and more efficient and complete banking market. Second, the acrosscountries convergence is necessary for euro-zone accession perspective, some CEE countries being already members of euro-zone. In banking-oriented economies as CEE countries are, the transmission of the monetary policy depends mostly on the willingness of banks to adjust their loan and deposit rates on the evolution of the central bank's instruments. Since the 
reaction of banking institutions depends itself on their market power and competitive behaviour, different convergent levels across countries may imply an asymmetric effect of the monetary policy. Finally, with different convergence levels between foreign and domestic banks, an asymmetric impact may occur within CEE economies too, but at lesser extent due to compensation measures.

Other contribution to the banking literature of transition countries is precisely the estimation of convergence levels for different measures of bank competition. In order to test the convergence, we apply the two major concepts of convergence, $\beta$-convergence and $\sigma$ convergence. Unlike other studies (Weill, 2009, 2013), we make these tests at microeconomic level, that is, across banks of each country and not across banking markets. Thus, $\beta$ convergence implies that banks with less competitive behaviour know faster increase of their competitiveness than banks with more competitive incentives. $\sigma$-convergence is considered when each bank's competitive measure is converging to the country's average level. More precisely, it implies that the deviation from the average level diminishes over time.

Finally, unlike previous studies, our microeconomic approach allows the examination of the convergence of bank competitive measures within each CEE country and the global convergence across all studied CEE banking markets. For the latter, using the results for within-country convergence, we determine with precision the groups of countries, whose banks have a similar competitive behaviour. This approach also allows the examination of the role of ownership profile on the convergence of bank competition.

In order to investigate the convergence of CEE banks' competitive behaviour and the role of ownership profile, we firstly briefly present the literature survey on the bank competition in European countries, especially in CEE banking markets, and emphasize the lack of convergence obtained by previous works. In section 3 , we outline the methodology used to estimate the bank competitive measures, that is, the Lerner index, the Boone indicator and the $\mathrm{H}$-statistic, and our approach for convergence tests. In section 4, we describe our data and variables, and explain and comment our empirical results. Finally, we conclude in section 5.

\section{Related literature}

Expected effects in the banking industry of CEE countries' accession to EU were an increased competition with new banking products and lower bank prices. However, few studies on EU old members find an imperfect competition in 1990s and some divergences across types of banks (De Bandt and Davis, 2000) and across countries (Molyneux et al., 1994; Hondroyiannis et al., 1999; Coccorese, 2004).

The lack of convergence of bank competition is also observed for CEE countries. Considering Panzar and Rosse's (1987) methodology to estimate the H-statistic as measure of bank competition, Gelos and Roldós (2002) find that bank competition increased in the Czech Republic and decreased in Hungary and Poland from 1994 to 1999. With the same methodology, Mamatzakis et al. (2005) investigate the competitive conditions in the banking industry in the South and Eastern European region over the period 1998-2002, and find a monopolisitic competition for these banking industries. Dracos and Konstantinou (2005) obtained similar results.

The main shortcoming of the previous approach is the estimation of an average measure of bank competition over the time sample, which therefore does not allow the determination of the evolution of competition level. Considering a translog revenue function instead of a linear form, Lapteacru and Nys (2011) overcome this problem and estimate the H-statistic for each bank and for each year over 1999-2006 period. They find that the competitive behaviour of Hungarian, Latvian, Lithuanian, Romanian, and Czech banks weakens and it strengthens for Slovak and Slovenian banking institutions. Lapteacru (2014) also highlights huge differences. Thus, these first studies clearly show either different levels or different trends of 
bank competition, presuming lack of convergence.

A divergence in banks' competitive behaviour is also found with the Lerner index, which is defined as mark-up of output price over marginal cost and measures the market power of banks. Lapteacru (2014) points out that these two measures are conceptually completely different and shows, on the example of CEE countries, that banks with higher H-statistic can have higher market power, and vice versa. Only in Slovakia does fierce market competition imply a decrease in market power. Agoraki et al. (2011) find an increase in market power for Bulgarian, Czech, Hungarian, Estonian and Latvian banks and a decrease of the Lerner index of banking institutions of Poland and Slovakia over 1998-2005 period. The results of Lapteacru and Nys (2011) suggest the same evolution for Czech, Hungarian and Estonian banking institutions and no trend for Latvian, Slovak and Slovenian banks. Thus, with the Lerner index we also may presume the lack of convergence of CEE banks' competitiveness. However, none of these studies made convergence tests and none of them considered the role of foreign banks in the creation of convergence groups.

The only paper that made convergence tests on bank competition in the EU, including in CEE countries, is that of Weill (2013). Applying both competitive measures, he finds no trend in market power of CEE banks and opposite evolution of the H-statistic: decreases for Bulgaria, the Czech Republic, Latvia, Poland, Romania and Slovenia, and increases for Estonia, Hungary, Lithuania and Slovakia. His convergence test imposes the determination of a global convergence level for all EU banking markets. Consequently, even if he concludes on the convergence in bank competition across European countries, his results do not provide information neither about the convergence within each country nor about the convergence groups of countries.

All these subjects (or their omission) guide our empirical investigation. In the following, we provide a methodological overview of applied measures of bank competition, which are the Lerner index, the Boone indicator and the H-statistic.

\section{Methodology}

In this section, we present the methodology used to estimate employed measures of bank competition. We then explain our within-country convergence tests and the creation of group of countries with same levels of bank competition, which will precisely uncover the acrosscountries convergence.

\subsection{Measures of bank competition}

We will apply the Lerner index, the Boone indicator and the H-statistic, because they do not measure the same aspects of competition (Degryse et al., 2009; Lapteacru, 2014).

\subsubsection{Lerner Index}

The Lerner index is a structural measure that is defined as the mark-up of price over the bank's marginal cost:

$L_{i t}=\frac{p_{i t}-\frac{\partial C_{i t}}{\partial y_{i t}}}{p_{i t}}$,

where $p_{i t}$ represents the average price of bank $i$ 's output at time $t, C_{i t}$ is the bank's total cost and $y_{i t}$ is its output. Banks have no market power if $L_{i t}=0$, and the bank's market power increases with an increase in $L_{i t}$. The Lerner index is computed for each bank and for each year and has been applied to assess the evolution bank competition (Fernández de Guevara et al., 2007; Carbó et al., 2009; Weill, 2013) and to determine its factors (Berger et al., 2009; Fungacova and Weill, 2013).

The econometric methodology consists in the estimation of the marginal cost of banks. 
The banking literature mostly uses either the total amount of loans (Pruteanu-Podpiera et al., 2008; Solís and Maudos, 2008) or total assets (Fernández de Guevara et al., 2007; Carbó et al., 2009; Weill, 2013) as bank output. This study considers three bank products that are principal sources of revenue for CEE banks: non-financial loans, bank loans and investment assets, which are produced with funds, labour and physical capital. The translog cost function consists, therefore, of three inputs and three types of outputs as following:

$$
\begin{aligned}
\ln C_{i t} & =c_{0}+\alpha_{i}+\mu_{t}+\sum_{j=1}^{3} \beta_{j} \ln w_{j, i t}+\sum_{m=1}^{3} \gamma_{m} \ln y_{m, i t}+\frac{1}{2} \sum_{k=1}^{3} \sum_{l=1}^{3} \varphi_{k l} \ln w_{k, i t} \ln w_{l, i t} \\
& +\sum_{m=1}^{3} \sum_{k=1}^{3} \chi_{m k} \ln w_{k, i t} \ln y_{m, i t}+\frac{1}{2} \sum_{m=1}^{3} \sum_{s=1}^{3} \rho_{m s} \ln y_{m, i t} \ln y_{s, i t} \\
& +\sum_{m=1}^{3} \omega_{1 m} \ln y_{m, i t} \ln g d p_{t}+\varepsilon_{i t}+\sum_{m=1}^{3} \omega_{2 m} \ln y_{m, i t} g r g d p_{t}+\varepsilon_{i t},
\end{aligned}
$$

where total costs $C_{i t}$ comprise operational and non-operational costs. $y_{m}$ is the banking product of type $m$ : non-financial loans, bank loans and other earning-assets. $w_{1}$ is the price of funds that is measured as the ratio of interest expenses to total interest-bearing liabilities, $w_{2}$ is the price of labour that is calculated as the ratio of wage expense to total assets ${ }^{1}$, and $w_{3}$ is the price of other inputs that is estimated as the ratio of other operational expenses to total assets ${ }^{2}$. $g d p_{t}$ represents real GDP in year $t$ of the country of bank $i$, and $g r g d p_{t}$ is real GDP growth. The evolution of banks' costs may also be affected by the business cycle, which explains the presence of economic indicators related to cross-product terms.

As homogeneous function of degree 1 , the cost function must respect the following homogeneity conditions:

$\sum_{j=1}^{3} \beta_{j}=1 \sum_{k=1}^{3} \chi_{m k}=0(m=[1,3]) \sum_{k=1}^{3} \varphi_{k l}=0(l=[1,3])$.

Similarly, the conditions of symmetry are also considered: $\varphi_{k l}=\varphi_{l k}(l, k=[1,3]), \rho_{m s}=\rho_{s m}(m, s$ $=[1,3])$.

Equation (2) is regressed using a panel data model with fixed individual effects, $\alpha_{i}$, and fixed time effects, $\mu_{t}$, and the results are applied in the estimation of the marginal cost according to the following expression:

$$
\begin{aligned}
m c_{i t} & =\frac{\partial C_{i t}}{\partial\left(y_{1, i t}+y_{2, i t}+y_{3, i t}\right)}=\left[\sum_{m=1}^{3} \gamma_{m}+\sum_{m=1}^{3} \sum_{k=1}^{3} \chi_{m k} \ln w_{k, i t}+\sum_{m=1}^{3} \sum_{s=1}^{3} \rho_{m s} \ln y_{s}\right. \\
& \left.+\sum_{m=1}^{3} \omega_{1 m} \ln g d p_{t}+\sum_{m=1}^{3} \omega_{2 m} g r g d p_{t}\right] \times \frac{C_{i t}}{y_{1, i t}+y_{2, i t}+y_{3, i t}} .
\end{aligned}
$$

The results are then employed in the estimation of the Lerner index $L_{i t}$ (eq. 1), computing the average price of bank output as the ratio of total revenues to interest-earning assets, $p_{i t}=$ $T R_{i t} /\left(y_{1, i t}+y_{2, i t}+y_{3, i t}\right)$.

\footnotetext{
${ }^{1}$ Following many other studies (Fernández de Guevara et al., 2007; Maudos and Fernández de Guevara, 2007; Solís and Maudos, 2008; Lapteacru, 2014) and because of the data availability, we use total assets instead of the number of employees. This will not qualitatively affect our results because total assets correlate significantly and positively with the number of employees.

${ }^{2}$ Many authors use the price of physical capital instead of the price of other inputs. We employ the latter because the data for its calculation are available for the most of banks and because it comprises all other inputs and not a particular one.
} 


\subsubsection{Boone indicator}

Boone (2008) suggests to measure how (cost) inefficiency, as reflected by differences in marginal cost, influences bank profitability. He proposes an indicator of competition based on idea that more efficient firms gain higher market shares, and that this effect will be stronger in more competitive banking market. Thanks to its important advantages, namely strong theoretical foundations and the consideration of efficiency-competitive behaviour nexus, this indicator has begun to be intensely used in recent banking literature: to measure the role of bank competition on the firms' access to finance (Love and Martinez Peria, 2015), to assess the impact of financial reforms on bank competition through different institutional regimes (Delis, 2012), to revisit the relationship between banking market competition and risk-taking (Tabak et al., 2012), or just to measure the bank competition (Van Leuvensteijn et al., 2011).

It is often calculated as the elasticity of profits to marginal cost, based on idea that more efficient firms, that is, with lower marginal cost, earn more profits (Degryse et al., 2009; Buch et al., 2013; Leon, 2015). However, higher profits do not necessarily mean more market shares, towards should lead the concept of Boone (2008) of bank competitiveness. Van Leuvensteijn et al. (2013) develop the theoretical approach of Boone (2008) for banking industry and support the idea that the Boone indicator must be directly considered as the elasticity of market share to marginal cost as in Bikker and van Leuvensteijn (2008). We follow this direct competitive effect of bank efficiency on market share gain, and apply the following econometric model to compute the Boone indicator:

$$
\begin{aligned}
\ln m s_{i t} & =\pi_{0}+\pi_{1 i}+v_{t}+\theta_{1} \ln m c_{i t}+\theta_{2} \ln m c_{i t} \times \ln m c_{i t}+\theta_{3} \ln m c_{i t} \times \ln g d p_{t} \\
& +\theta_{4} \ln m c_{i t} \times g r g d p_{t}+\varepsilon_{i t},
\end{aligned}
$$

where $m s_{i t}=$ earn. assets ${ }_{i t} / \sum_{i}$ earn. assets ${ }_{i t}$ stands for earning assets share for bank $i$ in year $t$. As for bank costs, business cycle may also affect the evolution of market share. As the elasticity of market share to marginal cost, the Boone indicator is calculated as following:

Boone $_{i t}=\theta_{1}+2 \theta_{2} \ln \left(m c_{i t}\right)+\theta_{3} \ln \left(g d p_{t}\right)+\theta_{4} g r g d p_{t}$.

\subsubsection{H-statistic}

Other aspect about the competitive behaviour of banks is addressed by the H-statistic of Panzar and Rosse (1987), which is the aggregate elasticity of banks' revenue to input prices. Its authors show that the way in which the variation of input prices is transmitted to banks' revenue depends on the level of competition in the market. The H-statistic equals to one in a perfectly competitive market and ranges between 0 and 1 for banks operating under monopolistic competition. It is less than or equal to zero for banks that collude.

Regarding its concept, to compute the $\mathrm{H}$-statistic we firstly must determine the revenue function of banks and, as it may also change with the economic context, we use the following translog form:

$$
\begin{aligned}
\ln T R_{i t} & =\mathrm{a}_{0}+\vartheta_{\mathrm{i}}+v_{t}+\sum_{j=1}^{3} \lambda_{j} \ln w_{j, i t}+\psi_{1} \ln T A_{i t}+\psi_{2} \ln \operatorname{Loan}_{i t}+\frac{1}{2} \sum_{k=1}^{3} \sum_{l=1}^{3} \kappa_{k l} \ln w_{k, i t} \ln w_{l, i t} \\
& +\sum_{k=1}^{3} \phi_{1 k} \ln w_{k, i t} \ln T A_{i t}+\sum_{k=1}^{3} \phi_{2 k} \ln w_{k, i t} \operatorname{Loan}_{i t} \\
& +\sum_{k=1}^{3} \phi_{3 k} \ln w_{k, i t} \ln g d p_{t}+\sum_{k=1}^{3} \phi_{4 k} \ln w_{k, i t} \operatorname{grgdp}_{t}+\varepsilon_{i t}
\end{aligned}
$$

where $T R_{i t}$ stands for total revenue of bank $i$ in year $t, T A_{i t}$ represents total assets and $L_{o a n}$ ratio of loans on total assets. The last two variables take into account the differences in size and business model, akin to De Bandt and Davis (2000), Bikker and Haaf (2002), Weill (2013). Thus, the H-statistic is equal to 


$$
\begin{aligned}
H_{i t} & =\sum_{k=1}^{3} \frac{\partial T R_{i t}}{\partial w_{k, i t}} \times \frac{w_{k, i t}}{T R_{i t}}=\sum_{k=1}^{3} \lambda_{j}+\sum_{k=1}^{3} \sum_{l=1}^{3} \kappa_{k l} \ln w_{l, i t}+\sum_{k=1}^{3} \phi_{1 k} \ln T A_{i t} \\
& +\sum_{k=1}^{3} \phi_{2 k} \operatorname{Loan}_{i t}+\sum_{k=1}^{3} \phi_{3 k} \ln g d p_{t}+\sum_{k=1}^{3} \phi_{4 k} g r g d p_{t} .
\end{aligned}
$$

Related to works of Carbó et al. (2009), Lapteacru and Nys (2011) and Lapteacru (2014), our method allows the determination of individual H-statistics and thus the implementation of a homogeneous approach for all three competition measures.

\subsection{Convergence measures and tests}

We now present the methodology used to determine the convergence levels and to test the equality between them in order to uncover convergence groups of countries.

\subsubsection{Estimation of convergence levels and within-country convergence tests}

In order to estimate the convergence levels of bank competitive measures, $B C$ ( $L$, Boone and $H$ ), we apply a dynamic equation based on an autoregressive process according to which the convergence level is obtained for $E\left(B C_{i t}\right)=E\left(B C_{i t-k}\right)(\forall k=1, \ldots, p)$. To test the convergence of bank competitiveness within each country and to find the convergence level, we thus regress the following equation using a panel data model with fixed individual and time effects:

$B C_{i t}=a_{0}+\alpha_{i}+\mu_{t}+\sum_{k=1}^{p} a_{k} B C_{i t-k}+u_{i t}$

Obtained when the expected value of bank competitiveness does not change over time, the convergence level is calculated as follows:

$$
C L=\frac{a_{0}}{1-\sum_{k=1}^{p} a_{k}} \text {. }
$$

The $B C_{i t}$ is converging if the $p$ solutions with respect to $\lambda$ of the homogeneous equation

$$
\begin{array}{r}
\lambda^{p}-\sum_{k=1}^{p} \lambda^{p-k} a_{k} \\
=0
\end{array}
$$

are $\left|\hat{\lambda}_{i}\right|<1$ for any $i=1, \ldots, p$.

This statistical convergence meaning is completed with other two concepts of convergence: $\beta$-convergence and $\sigma$-convergence (Barro and Sala-I-Martin, 1991). The former means that banks with less competitiveness experience faster increase in their competitive behaviour. Some limits of this test have been, nevertheless, evoked by Quah (1996). First, the banks with low previous level of competition could overpass the banks with high previous level and the evolution of bank competition become divergent. Second, taking into account that the reduction in dispersion implies convergence, the $\beta$-convergence test provides no information on the dispersion of bank competition measure.

In the banking literature, the $\beta$-convergence test has been performed for the convergence of bank efficiency (Weill, 2009) and competition (Weill, 2013) across European countries. Unlike to these studies, we check the convergence of bank competition within each country applying the following equation:

$B C_{i t}-B C_{i t-1}=\beta_{0}+\alpha_{i}+\mu_{t}+\beta_{1} B C_{i t-1}+\varepsilon_{i t}$.

There is $\beta$-convergence if $\beta_{1}<0$. Moreover, higher is its absolute value, faster pervious $B C$ values approach to current values. However, the value of $\beta_{1}$ cannot really allow to test the convergence because, for high absolute values, previous levels of $B C$ could overpass the current ones and the process become divergent. 
Contrary to the $\beta$-convergence test, $\sigma$-convergence test aims to investigate the evolution of the dispersion. There is then convergence if the dispersion diminishes over time and we thus overcome the divergent effect of the previous test. The $\sigma$-convergence test measures how quickly each bank's competition measure converges to countries' average level for each year and the estimation is made with the following equation:

$\operatorname{Dev}_{i t}=\sigma_{0}+\alpha_{i}+\sigma_{1}$ time $_{t}+\varepsilon_{i t}$,

where $D e v_{i t}$ denotes the deviation of the bank competition $B C_{i t}$ from its across-banks average level in year $t, \overline{B C}_{t}$, that is, $D e v_{i t}=\left|B C_{i t}-\overline{B C}_{t}\right|$. There is $\sigma$-convergence if the coefficient $\sigma_{1}$ is negative and its absolute value indicates the speed of convergence.

\subsubsection{Across-countries tests of convergence}

The most important contributions of our paper are the determination of convergence levels of bank competition measures and the establishment of groups of countries with same levels. The Wald test of equality between competition levels of $k$ different countries will allow to bring together the countries for which it cannot reject the null hypothesis $C L_{1}=$ $C L_{2}=\cdots=C L_{k}$. The Wald statistic for nonlinear restriction is (Greene, 2012, p. 172): $W=(\hat{\mathbf{c}}-\mathbf{q})^{\prime}\{\operatorname{Var}(\hat{\mathbf{c}})\}^{-1}(\hat{\mathbf{c}}-\mathbf{q})$,

where $\hat{\mathbf{c}}-\mathbf{q}$ is the vector of $k-1$ differences between a reference convergence level and other levels and $\operatorname{Var}(\hat{\mathbf{c}})=\widehat{\mathbf{G}} \operatorname{Var}(\widehat{\boldsymbol{\beta}}) \widehat{\mathbf{G}}^{\prime}$. Other formulas are: $\widehat{\mathbf{G}}=\partial \mathbf{c}(\widehat{\boldsymbol{\beta}}) / \partial \widehat{\boldsymbol{\beta}}^{\prime}$, where $\mathbf{c}(\widehat{\boldsymbol{\beta}})$ is the vector of tested convergence levels that are computed with equation (10) and $\widehat{\boldsymbol{\beta}}$ is the vector of estimated coefficients of equation (9) that appear in equation (10). $\operatorname{Var}(\widehat{\boldsymbol{\beta}})$ is the variance-covariance matrix of regressions of equation (9) for convergence levels that are subject of the Wald test. Finally, the Wald statistic $W$ has a chi-squared distribution with degrees of freedom equal to the number of restrictions, that is $k-1$.

\section{Data and results}

In this section, we firstly present our data and describe our variables. We then provide our main findings for CEE banks' competitiveness, their convergence levels and our results about groups of countries with same bank competitive environment.

\subsection{Data and variables}

Our sample of countries consists of 322 banks from ten CEE economies, including Bulgaria, the Czech Republic, Hungary, Estonia, Latvia, Lithuania, Poland, Romania, Slovakia and Slovenia. Accounting data for individual banks are extracted on an annual basis from Bankscope Fitch IBCA in millions of USD. Macroeconomic variables, as real GDP, real GDP growth and consumption price index, are obtained from DataStream for all transition countries. The sample period is from 1995 to 2013 and includes crisis events from nineties and from 2008.

For the 322 banks, 3,494 observations were collected for a 19-year period. Table 1 displays some descriptive statistics for the bank sample, which consists of banks of all sizes and covers almost entirely the CEE banking markets. Bank loans and other earning assets account for a substantial share of total outputs and were therefore considered separately in our regression equations.

All the regressions, with the exception of those for Estonia, are performed by considering the auto-correlation and the heteroscedasticity of the error term. The auto-correlation test for Estonian banks cannot reject the hypothesis of the absence of auto-correlation and therefore only the heteroscedasticity is corrected. All the regressions are also made with individual and time fixed effects. For equation (13), the time fixed effects are not included. 
Table 1. Descriptive statistics on used variables, 1995-2013.

\begin{tabular}{|c|c|c|c|c|c|c|c|c|c|c|c|c|c|}
\hline & $\begin{array}{l}\text { Nr. of } \\
\text { obs. }\end{array}$ & $\begin{array}{l}\text { Total } \\
\text { costs }\end{array}$ & $\begin{array}{l}\text { Total } \\
\text { revenues }\end{array}$ & $\begin{array}{l}\text { Non-fin. } \\
\text { loans }\end{array}$ & $\begin{array}{l}\text { Bank } \\
\text { loans }\end{array}$ & $\begin{array}{l}\text { Other earn. } \\
\text { assets }\end{array}$ & $\begin{array}{l}\text { Pr. of borr. } \\
\text { funds }\end{array}$ & $\begin{array}{l}\text { Pr. of } \\
\text { labour }\end{array}$ & $\begin{array}{l}\text { Pr. of } \\
\text { other inp. }\end{array}$ & $\begin{array}{l}\text { Total } \\
\text { assets }\end{array}$ & $\begin{array}{l}\text { Loan on } \\
\text { assets }\end{array}$ & $\begin{array}{l}\text { Real } \\
\text { GDP }\end{array}$ & $\begin{array}{l}\text { GDP } \\
\text { growth }\end{array}$ \\
\hline Bulgaria & 365 & 454 & 525 & 845 & 392 & 476 & 0.044 & 0.020 & 0.032 & 1924 & 0.54 & 27,257 & 2.62 \\
\hline Czech Rep. & 373 & 275 & 386 & 2,957 & 1,253 & 1,359 & 0.044 & 0.008 & 0.019 & 5923 & 0.46 & 123,572 & 2.59 \\
\hline Hungary & 414 & 288 & 351 & 1,785 & 450 & 674 & 0.066 & 0.017 & 0.030 & 3182 & 0.53 & 99,883 & 1.93 \\
\hline Estonia & 118 & 101 & 152 & 1,888 & 204 & 170 & 0.027 & 0.019 & 0.022 & 2517 & 0.57 & 12,270 & 4.91 \\
\hline Latvia & 341 & 35 & 48 & 474 & 142 & 97 & 0.024 & 0.017 & 0.026 & 764 & 0.45 & 13,845 & 4.50 \\
\hline Lithuania & 174 & 62 & 79 & 944 & 132 & 167 & 0.032 & 0.022 & 0.022 & 1369 & 0.58 & 65,614 & 4.41 \\
\hline Poland & 687 & 310 & 410 & 2,584 & 468 & 1,087 & 0.061 & 0.017 & 0.021 & 4498 & 0.54 & 301,662 & 4.28 \\
\hline Romania & 409 & 593 & 773 & 2,130 & 515 & 421 & 0.082 & 0.028 & 0.034 & 3757 & 0.51 & 97,359 & 2.37 \\
\hline Slovakia & 304 & 159 & 203 & 1,487 & 380 & 482 & 0.044 & 0.010 & 0.022 & 2807 & 0.51 & 61,047 & 4.29 \\
\hline Slovenia & 303 & 125 & 158 & 1,475 & 245 & 492 & 0.038 & 0.014 & 0.014 & 2275 & 0.61 & 26,985 & 3.28 \\
\hline Average & 3,494 & 240 & 309 & 1,657 & 418 & 543 & 0.046 & 0.017 & 0.024 & 2902 & 0.53 & 82949 & 3.52 \\
\hline
\end{tabular}

Notes: This table displays descriptive statistics for the variables used in our estimations. The financial results, outputs and real GDP are in constant millions of USD. Output and input prices are unitless and real GDP growth rate is expressed as a percentage. The number of observations is 3,494. 


\subsection{Evolution of bank competition}

We investigate the evolution of bank competition measured with the Lerner index, the Boone indicator and with the H-statistic for CEE banks between 1995 and 2013 and examine the difference in competitive behaviour between domestic and foreign banks. The mean values for each country and each year are displayed in Table 2 and they unveil some important observations.

First, the mean values of our three bank competition measures range globally within theoretical limits. The Lerner index is around 0.25 and the H-statistic around 0.65 , with important deviations depending on years and countries. Therefore, the CEE banks have some market power, which corresponds to works of Lapteacru and Nys (2011), Weill (2013) and Lapteacru (2014) on CEE banks and corroborate also the findings of Fernández de Guevara et al. (2007) and Carbó et al. (2009) on EU banks.

Second, as suggested and proved by Lapteacru (2014) on the experience of CEE banks, the market power, measured by the Lerner index, and the competitive behaviour, expressed by the H-statistic, are conceptually very different. The former measures the capability of banks to set a price higher than their marginal cost and the latter assesses the adjustment of bank revenues on the evolution of input prices. As such, more competitive banks do not always have less market power, because of the revenue and production reactions of banks to total costs. More precisely, if the elasticities of revenue and of earning assets with respect to costs evolve in the same direction, then the Lerner index and the H-statistic provide the same information about the competitiveness of banks. Our results are in the same vein as those of Weill (2013) and Lapteacru (2014) and suggest that more competitive banks do not always have less market power. The Lerner index is, for example, very sensitive to crisis events, when the price of bank product and services is set very close to marginal cost and sometimes it is even lower than the latter. Except for Poland and Slovenia, the banks of all other CEE countries have either negative or very close to zero Lerner indices during the crises of nineties and of 2008. On the other hand, except for Lithuania, the H-statistic does not show any important changing during the crisis events and, except for Slovakia, this is also the case of the Boone indicator.

Overall, with the exception of crisis periods when market power of banks decreases a lot, the evolution of the Lerner index of each country shows no discernible trend. As for an overall analysis, the market power of CEE banks lowers until 2005 and becomes stronger after ('All counties' side of table 2). This result does not corroborate the evolution of the Boone indicator and of the H-statistic. The bank competition slightly increases with the Boone indicator and it slightly decreases with the H-statistic. However, when we make an examination across CEE countries, we observe different patterns. In Bulgaria, the Czech Republic and Slovakia the market power of banks increases and competitive behaviour lowers with the $\mathrm{H}$-statistic and accentuates with the Boone indicator. The same patterns of the Boone indicator and of the H-statistic but with a decrease in banks' market power are observed in Hungary and Romania. Lithuania is the only country where the Boone indicator and the $\mathrm{H}$ statistic suggest simultaneously the reduction of bank competition, and Poland is the only country where no measure unveils a trend.

Third, foreign banks have, on average, different competitive behaviour than their domestic counterparts and ownership matters for all bank competition measures ('All countries' side of table 2). In normal periods, foreign banks have lower market power and they resist better to crises, setting higher prices than marginal cost, particularly after 2008. The evolution of the Boone indicator registers a reversal of trend in 2005; after this year, foreign banks become more competitive than their domestic counterparts. And the H-statistic shows higher competition for foreign banking institutions over all period. Since all three measures consider different meanings of competition, we cannot conclude on contradictory 
Table 2. Estimations of bank competition.

\begin{tabular}{|c|c|c|c|c|c|c|c|c|c|c|c|c|c|c|c|c|c|c|c|}
\hline & 1995 & 1996 & 1997 & 1998 & 1999 & 2000 & 2001 & 2002 & 2003 & 2004 & 2005 & 2006 & 2007 & 2008 & 2009 & 2010 & 2011 & 2012 & 2013 \\
\hline \multicolumn{20}{|l|}{ Bulgaria } \\
\hline Lerner $_{f}$ & - & 0.417 & 0.659 & -0.109 & 0.155 & 0.192 & 0.147 & 0.197 & 0.285 & 0.328 & 0.364 & 0.356 & 0.319 & 0.312 & 0.314 & 0.332 & 0.252 & 0.241 & 0.289 \\
\hline Lerner $_{d}$ & 0.161 & 0.340 & 0.472 & 0.173 & 0.323 & 0.289 & 0.267 & 0.241 & 0.234 & 0.261 & 0.216 & 0.188 & 0.298 & 0.118 & 0.271 & 0.156 & 0.096 & 0.008 & 0.026 \\
\hline Lerner & 0.161 & 0.351 & 0.513 & 0.094 & 0.261 & 0.252 & 0.201 & 0.216 & 0.265 & 0.301 & 0.311 & 0.297 & 0.313 & 0.247 & 0.300 & 0.270 & 0.190 & 0.148 & 0.172 \\
\hline Beta $_{f}$ & - & -0.078 & -0.329 & -0.483 & -0.463 & -0.442 & -0.510 & -0.589 & -0.629 & -0.688 & -0.742 & -0.780 & -0.814 & -0.792 & -0.665 & -0.742 & -0.743 & -0.732 & -0.795 \\
\hline Beta $_{d}$ & -0.087 & 0.203 & -0.194 & -0.469 & -0.452 & -0.495 & -0.520 & -0.565 & -0.605 & -0.635 & -0.649 & -0.683 & -0.787 & -0.708 & -0.604 & -0.697 & -0.722 & -0.705 & -0.748 \\
\hline Beta & -0.087 & 0.163 & -0.223 & -0.473 & -0.456 & -0.475 & -0.515 & -0.578 & -0.620 & -0.666 & -0.709 & -0.747 & -0.805 & -0.764 & -0.645 & -0.726 & -0.735 & -0.721 & -0.774 \\
\hline Hstat $_{f}$ & - & 0.609 & 0.582 & 0.598 & 0.567 & 0.582 & 0.554 & 0.535 & 0.519 & 0.505 & 0.476 & 0.460 & 0.445 & 0.417 & 0.333 & 0.391 & 0.394 & 0.376 & 0.382 \\
\hline Hstat $_{d}$ & 0.777 & 0.688 & 0.641 & 0.624 & 0.580 & 0.571 & 0.537 & 0.534 & 0.523 & 0.511 & 0.471 & 0.445 & 0.438 & 0.396 & 0.316 & 0.376 & 0.385 & 0.373 & 0.369 \\
\hline Hstat & 0.777 & 0.676 & 0.629 & 0.617 & 0.575 & 0.575 & 0.546 & 0.535 & 0.521 & 0.508 & 0.474 & 0.455 & 0.443 & 0.410 & 0.327 & 0.386 & 0.390 & 0.375 & 0.376 \\
\hline \multicolumn{20}{|c|}{ Czech Rep. } \\
\hline Lerner $_{f}$ & 0.283 & 0.279 & 0.262 & -0.250 & 0.234 & 0.231 & 0.247 & 0.300 & 0322 & 0.318 & 0.365 & 0.391 & 0.404 & 0.452 & 0.464 & 0.482 & 0.201 & 0.221 & 0.295 \\
\hline Lerner $_{d}$ & 0.173 & 0.044 & 0.091 & -0.043 & 0.066 & -0.303 & 0.296 & 0.309 & 0.350 & 0.261 & 0.399 & 0.369 & 0.454 & 0.395 & 0.420 & 0.429 & 0.394 & 0.424 & 0.430 \\
\hline Lerner & 0.224 & 0.151 & 0.185 & -0.124 & 0.169 & 0.022 & 0.263 & 0.302 & 0.328 & 0.304 & 0.374 & 0.385 & 0.414 & 0.438 & 0.453 & 0.465 & 0.258 & 0.277 & 0.335 \\
\hline Beta $_{f}$ & -0.114 & -0.195 & -0.291 & -0.335 & -0.260 & -0.190 & -0.221 & -0.223 & -0.189 & -0.186 & -0.186 & -0.204 & -0.278 & -0.334 & -0.419 & -0.308 & -0.348 & -0.390 & -0.364 \\
\hline Beta $_{d}$ & -0.181 & -0.271 & -0.358 & -0.334 & -0.270 & -0.198 & -0.232 & -0.179 & -0.200 & -0.227 & -0.198 & -0.249 & -0.279 & -0.341 & -0.440 & -0.329 & -0.359 & -0.369 & -0.322 \\
\hline Beta & -0.151 & -0.237 & -0.320 & -0.328 & -0.260 & -0.193 & -0.225 & -0.212 & -0.192 & -0.195 & -0.189 & -0.215 & -0.278 & -0.336 & -0.424 & -0.315 & -0.351 & -0.384 & -0.351 \\
\hline Hstat $_{f}$ & 0.845 & 0.806 & 0.725 & 0.794 & 0.836 & 0.840 & 0.816 & 0.787 & 0.782 & 0.781 & 0.801 & 0.768 & 0.724 & 0.637 & 0.545 & 0.627 & 0.603 & 0.557 & 0.572 \\
\hline Hstat $_{d}$ & 0.903 & 0.903 & 0.847 & 0.829 & 0.812 & 0.893 & 0.823 & 0.751 & 0.713 & 0.686 & 0.663 & 0.659 & 0.613 & 0.591 & 0.494 & 0.551 & 0.559 & 0.570 & 0.562 \\
\hline Hstat & 0.878 & 0.859 & 0.802 & 0.827 & 0.831 & 0.861 & 0.818 & 0.778 & 0.768 & 0.758 & 0.765 & 0.739 & 0.701 & 0.625 & 0.532 & 0.603 & 0.590 & 0.560 & 0.569 \\
\hline \multicolumn{20}{|c|}{ Hungary } \\
\hline Lerner $_{f}$ & 0.293 & 0.266 & 0.202 & 0.151 & 0.139 & 0.169 & 0.227 & 0.215 & 0.215 & 0.226 & 0.234 & 0.175 & 0.054 & 0.108 & 0.192 & 0.272 & 0.272 & 0.197 & 0.233 \\
\hline Lerner $_{d}$ & 0.170 & 0.175 & 0.085 & -0.213 & 0.176 & 0.223 & 0.241 & -0.102 & 0.142 & 0.346 & 0.331 & 0.307 & 0.253 & 0.175 & 0.254 & 0.022 & -0.003 & 0.049 & 0.047 \\
\hline Lerner & 0.238 & 0.230 & 0.165 & 0.030 & 0.149 & 0.182 & 0.232 & 0.146 & 0.201 & 0.247 & 0.254 & 0.201 & 0.102 & 0.120 & 0.207 & 0.184 & 0.167 & 0.141 & 0.159 \\
\hline Beta $_{f}$ & -0.086 & -0.109 & -0.120 & -0.138 & -0.195 & -0.247 & -0.300 & -0.340 & -0.405 & -0.434 & -0.506 & -0.548 & -0.579 & -0.585 & -0.580 & -0.542 & -0.571 & -0.568 & -0.566 \\
\hline Beta $_{d}$ & -0.050 & -0.076 & -0.085 & -0.108 & -0.184 & -0.246 & -0.324 & -0.360 & -0.409 & -0.475 & -0.526 & -0.563 & -0.594 & -0.608 & -0.609 & -0.534 & -0.548 & -0.545 & -0.552 \\
\hline Beta & -0.070 & -0.096 & -0.109 & -0.128 & -0.192 & -0.246 & -0.308 & -0.344 & -0.406 & -0.441 & -0.510 & -0.551 & -0.582 & -0.590 & -0.587 & -0.539 & -0.562 & -0.559 & -0.560 \\
\hline Hstat $_{f}$ & 0.875 & 0.860 & 0.853 & 0.842 & 0.828 & 0.812 & 0.790 & 0.774 & 0.730 & 0.717 & 0.693 & 0.667 & 0.668 & 0.645 & 0.666 & 0.658 & 0.636 & 0.650 & 0.639 \\
\hline Hstat $_{d}$ & 0.832 & 0.839 & 0.848 & 0.843 & 0.815 & 0.785 & 0.765 & 0.753 & 0.749 & 0.695 & 0.700 & 0.679 & 0.678 & 0.612 & 0.639 & 0.695 & 0.697 & 0.694 & 0.667 \\
\hline Hstat & 0.856 & 0.851 & 0.851 & 0.842 & 0.825 & 0.806 & 0.782 & 0.769 & 0.734 & 0.713 & 0.695 & 0.669 & 0.670 & 0.639 & 0.659 & 0.671 & 0.659 & 0.667 & 0.650 \\
\hline
\end{tabular}


Table 2. Estimations of bank competition (cont.)

\begin{tabular}{|c|c|c|c|c|c|c|c|c|c|c|c|c|c|c|c|c|c|c|c|}
\hline & 1995 & 1996 & 1997 & 1998 & 1999 & 2000 & 2001 & 2002 & 2003 & 2004 & 2005 & 2006 & 2007 & 2008 & 2009 & 2010 & 2011 & 2012 & 2013 \\
\hline \multicolumn{20}{|l|}{ Estonia } \\
\hline Lerner $_{f}$ & - & - & - & - & 0.235 & 0.160 & 0.176 & 0.156 & 0.237 & 0.267 & 0.264 & 0.279 & 0.261 & 0.223 & 0.115 & 0.190 & 0.129 & 0.169 & 0.238 \\
\hline Lerner $_{d}$ & 0.122 & 0.127 & 0.157 & -0.112 & 0.000 & 0.166 & 0.212 & 0.207 & 0.181 & 0.249 & 0.254 & 0.414 & 0.626 & 0.543 & -1.002 & 0.321 & 0.291 & 0.359 & 0.447 \\
\hline Lerner & 0.122 & 0.127 & 0.157 & -0.112 & 0.059 & 0.163 & 0.197 & 0.182 & 0.209 & 0.258 & 0.259 & 0.356 & 0322 & 0.287 & -0.108 & 0.234 & 0.175 & 0.223 & 0.298 \\
\hline Beta $_{f}$ & - & - & - & - & -0.626 & -0.614 & -0.586 & -0.566 & -0.547 & -0.525 & -0.501 & -0.465 & -0.417 & -0.398 & -0.440 & -0.491 & -0.465 & -0.445 & -0.432 \\
\hline Beta $_{d}$ & -0.729 & -0.711 & -0.687 & -0.637 & -0.614 & -0.614 & -0.586 & -0.567 & -0.544 & -0.516 & -0.491 & -0.451 & -0.436 & -0.443 & -0.426 & -0.465 & -0.459 & -0.429 & -0.420 \\
\hline Beta & -0.729 & -0.711 & -0.687 & -0.637 & -0.617 & -0.614 & -0.586 & -0.567 & -0.545 & -0.520 & -0.496 & -0.457 & -0.420 & -0.407 & -0.437 & -0.482 & -0.464 & -0.441 & -0.428 \\
\hline Hstat $_{f}$ & - & - & - & - & 0.514 & 0.431 & 0.406 & 0.433 & 0.522 & 0.579 & 0.579 & 0.406 & 0.219 & 0.183 & 0.482 & 0.689 & 0.578 & 0.725 & 0.886 \\
\hline Hstat $_{d}$ & 0.616 & 0.626 & 0.590 & 0.460 & 0.450 & 0.460 & 0.542 & 0.620 & 0.611 & 0.669 & 0.614 & 0.386 & 0.376 & 0.489 & 0.871 & 0.397 & 0.386 & 0.388 & 0.446 \\
\hline Hstat & 0.616 & 0.626 & 0.590 & 0.460 & 0.466 & 0.448 & 0.488 & 0.526 & 0.567 & 0.624 & 0.596 & 0.395 & 0.245 & 0.244 & 0.560 & 0.592 & 0.523 & 0.629 & 0.760 \\
\hline \multicolumn{20}{|l|}{ Latvia } \\
\hline Lerner $_{f}$ & - & 0.235 & -0.885 & -0.026 & 0.185 & 0.240 & 0.185 & 0.237 & 0.256 & 0.240 & 0.272 & 0.213 & 0.158 & 0.143 & 0.109 & 0.043 & 0.176 & 0.253 & 0.338 \\
\hline Lerner $_{d}$ & 0.233 & 0.321 & 0.352 & -0.353 & 0.127 & 0.159 & 0.248 & 0.240 & 0.310 & 0.265 & 0.356 & 0.299 & 0.286 & 0.245 & 0.165 & 0.079 & 0.300 & 0.191 & 0.016 \\
\hline Lerner & 0.233 & 0.307 & 0.146 & -0.271 & 0.141 & 0.178 & 0.227 & 0.239 & 0.294 & 0.256 & 0.323 & 0.263 & 0.229 & 0.191 & 0.137 & 0.063 & 0.238 & 0.218 & 0.168 \\
\hline Beta $_{f}$ & - & -0.378 & -0.486 & -0.469 & -0.468 & -0.538 & -0.604 & -0.662 & -0.726 & -0.807 & -0.873 & -0.941 & -0.969 & -0.791 & -0.524 & -0.721 & -0.832 & -0.866 & -0.883 \\
\hline Beta $_{d}$ & -0.306 & -0.377 & -0.507 & -0.429 & -0.467 & -0.542 & -0.613 & -0.669 & -0.731 & -0.798 & -0.868 & -0.930 & -0.963 & -0.796 & -0.529 & -0.714 & -0.838 & -0.864 & -0.863 \\
\hline Beta & -0.306 & -0.377 & -0.503 & -0.439 & -0.467 & -0.541 & -0.610 & -0.667 & -0.729 & -0.801 & -0.870 & -0.934 & -0.966 & -0.794 & -0.526 & -0.717 & -0.835 & -0.865 & -0.872 \\
\hline Hstat $_{f}$ & - & 0.693 & 0.650 & 0.670 & 0.669 & 0.655 & 0.682 & 0.646 & 0.584 & 0.534 & 0.573 & 0.591 & 0.594 & 0.646 & 0.656 & 0.613 & 0.567 & 0.526 & 0.423 \\
\hline Hstat $_{d}$ & 0.717 & 0.626 & 0.617 & 0.730 & 0.682 & 0.656 & 0.664 & 0.607 & 0.586 & 0.551 & 0.560 & 0.584 & 0.594 & 0.598 & 0.603 & 0.588 & 0.521 & 0.541 & 0.512 \\
\hline Hstat & 0.717 & 0.637 & 0.622 & 0.715 & 0.679 & 0.656 & 0.670 & 0.619 & 0.585 & 0.545 & 0.565 & 0.587 & 0.594 & 0.623 & 0.629 & 0.599 & 0.544 & 0.534 & 0.470 \\
\hline \multicolumn{20}{|c|}{ Lithuania } \\
\hline Lerner $_{f}$ & - & - & - & - & -1.050 & -0.025 & -0.129 & 0.042 & 0.193 & 0.206 & 0.225 & 0.190 & 0.181 & 0.184 & 0.043 & 0.183 & 0.227 & 0.249 & 0.247 \\
\hline Lerner $_{d}$ & 0.144 & -0.039 & 0.026 & 0.126 & 0.143 & 0.118 & 0.110 & 0.189 & 0.190 & 0.213 & 0.207 & 0.243 & 0.232 & 0.092 & -0.263 & -0.041 & -0.104 & 0.177 & 0.085 \\
\hline Lerner & 0.144 & -0.039 & 0.026 & 0.126 & 0.024 & 0.103 & 0.030 & 0.107 & 0.192 & 0.209 & 0.218 & 0.211 & 0.201 & 0.143 & -0.096 & 0.081 & 0.080 & 0.222 & 0.187 \\
\hline Beta $_{f}$ & - & - & - & - & -0.642 & -0.496 & -0.666 & -0.475 & -0.309 & -0.222 & -0.127 & -0.175 & -0.103 & -0.239 & -0.332 & -0.248 & -0.156 & -0.116 & -0.063 \\
\hline Beta $_{d}$ & -1.027 & -0.881 & -0.769 & -0.786 & -0.805 & -0.729 & -0.664 & -0.600 & -0.460 & -0.368 & -0.297 & -0.283 & -0.289 & -0.443 & -0.596 & -0.422 & -0.350 & -0.248 & -0.228 \\
\hline Beta & -1.027 & -0.881 & -0.769 & -0.786 & -0.788 & -0.706 & -0.665 & -0.531 & -0.376 & -0.287 & -0.195 & -0.218 & -0.177 & -0.329 & -0.452 & -0.327 & -0.242 & -0.166 & -0.125 \\
\hline Hstat $_{f}$ & - & - & - & - & -0.649 & 0.137 & 0.619 & 0.374 & 0.462 & 0.428 & 0.499 & 0.623 & 0.668 & 0.674 & 0.131 & 0.632 & 0.536 & 0.344 & 0.168 \\
\hline Hstat $_{d}$ & 0.607 & 0.488 & 0.422 & 0.428 & 0.066 & 0.343 & 0.504 & 0.311 & 0.404 & 0.293 & 0.312 & 0.369 & 0.636 & 0.444 & -0.374 & 0.200 & 0.059 & -0.316 & -0.260 \\
\hline Hstat & 0.607 & 0.488 & 0.422 & 0.428 & -0.006 & 0.323 & 0.543 & 0.346 & 0.436 & 0.368 & 0.424 & 0.521 & 0.655 & 0.571 & -0.099 & 0.435 & 0.324 & 0.097 & 0.008 \\
\hline
\end{tabular}


Table 2. Estimations of bank competition (cont.)

\begin{tabular}{|c|c|c|c|c|c|c|c|c|c|c|c|c|c|c|c|c|c|c|c|}
\hline & 1995 & 1996 & 1997 & 1998 & 1999 & 2000 & 2001 & 2002 & 2003 & 2004 & 2005 & 2006 & 2007 & 2008 & 2009 & 2010 & 2011 & 2012 & 2013 \\
\hline \multicolumn{20}{|l|}{ Poland } \\
\hline Lerner $_{f}$ & 0.280 & 0.065 & 0.180 & 0.154 & 0.148 & 0.165 & 0.124 & 0.143 & 0.154 & 0.212 & 0.188 & 0.264 & 0.258 & 0.204 & 0.254 & 0.262 & 0.274 & 0.258 & 0.279 \\
\hline Lerner $_{d}$ & 0.212 & 0.203 & 0.178 & 0.170 & 0.167 & 0.156 & 0.135 & 0.164 & 0.066 & 0.247 & 0.114 & 0.225 & 0.268 & 0.053 & 0.106 & 0.186 & 0.214 & 0.197 & 0.239 \\
\hline Lerner & 0.229 & 0.159 & 0.178 & 0.163 & 0.159 & 0.160 & 0.128 & 0.149 & 0.127 & 0.223 & 0.167 & 0.253 & 0.260 & 0.164 & 0.215 & 0.241 & 0.256 & 0.242 & 0.264 \\
\hline Beta $_{f}$ & -0.753 & -0.778 & -0.845 & -0.828 & -0.693 & -0.850 & -0.742 & -0.647 & -0.589 & -0.680 & -0.666 & -0.730 & -0.832 & -0.861 & -0.702 & -0.724 & -0.803 & -0.782 & -0.699 \\
\hline Beta $_{d}$ & -0.797 & -0.811 & -0.861 & -0.830 & -0.769 & -0.881 & -0.733 & -0.614 & -0.625 & -0.714 & -0.697 & -0.713 & -0.779 & -0.852 & -0.728 & -0.837 & -0.881 & -0.843 & -0.727 \\
\hline Beta & -0.786 & -0.800 & -0.856 & -0.829 & -0.738 & -0.866 & -0.739 & -0.638 & -0.600 & -0.691 & -0.675 & -0.725 & -0.818 & -0.859 & -0.709 & -0.755 & -0.826 & -0.798 & -0.710 \\
\hline Hstat $_{f}$ & 0.762 & 0.709 & 0.754 & 0.694 & 0.712 & 0.704 & 0.623 & 0.644 & 0.773 & 0.818 & 0.754 & 0.868 & 0.886 & 0.821 & 0.722 & 0.797 & 0.795 & 0.740 & 0.744 \\
\hline Hstat $_{d}$ & 0.805 & 0.788 & 0.800 & 0.750 & 0.744 & 0.703 & 0.632 & 0.654 & 0.742 & 0.775 & 0.720 & 0.861 & 0.890 & 0.799 & 0.724 & 0.763 & 0.771 & 0.736 & 0.739 \\
\hline Hstat & 0.794 & 0.763 & 0.784 & 0.726 & 0.731 & 0.704 & 0.626 & 0.647 & 0.764 & 0.804 & 0.744 & 0.866 & 0.887 & 0.815 & 0.723 & 0.787 & 0.788 & 0.736 & 0.742 \\
\hline \multicolumn{20}{|c|}{ Romania } \\
\hline Lerner $_{f}$ & - & - & 0.265 & 0.233 & 0.188 & 0.201 & 0.187 & 0.229 & 0.207 & 0.213 & 0.208 & 0.211 & 0.234 & 0.200 & 0.186 & 0.269 & 0.208 & 0.137 & 0.186 \\
\hline Lerner $_{d}$ & 0.393 & 0.328 & 0.226 & 0.203 & 0.213 & 0.177 & 0.240 & 0.216 & 0.257 & 0.259 & 0.216 & 0.294 & 0.272 & 0.169 & 0.161 & -0.466 & -0.343 & -0.061 & 0.177 \\
\hline Lerner & 0.393 & 0.328 & 0.241 & 0.218 & 0.198 & 0.192 & 0.202 & 0.225 & 0.218 & 0.223 & 0.210 & 0.225 & 0.240 & 0.196 & 0.182 & 0.133 & 0.102 & 0.096 & 0.184 \\
\hline Beta $_{f}$ & - & - & -0.429 & -0.396 & -0.430 & -0.480 & -0.579 & -0.608 & -0.660 & -0.770 & -0.764 & -0.887 & -0.930 & -1.050 & -0.791 & -0.780 & -0.868 & -0.826 & -0.828 \\
\hline Beta $_{d}$ & -0.638 & -0.662 & -0.505 & -0.433 & -0.504 & -0.565 & -0.630 & -0.655 & -0.691 & -0.829 & -0.772 & -0.891 & -0.942 & -1.063 & -0.810 & -0.816 & -0.875 & -0.845 & -0.836 \\
\hline Beta & -0.638 & -0.662 & -0.476 & -0.414 & -0.461 & -0.510 & -0.593 & -0.623 & -0.668 & -0.783 & -0.766 & -0.888 & -0.932 & -1.052 & -0.794 & -0.787 & -0.869 & -0.830 & -0.830 \\
\hline Hstat $_{f}$ & - & - & 0.954 & 0.826 & 0.879 & 0.842 & 0.852 & 0.853 & 0.820 & 0.789 & 0.755 & 0.725 & 0.685 & 0.662 & 0.647 & 0.706 & 0.702 & 0.691 & 0.692 \\
\hline Hstat $_{d}$ & 0.712 & 0.722 & 0.770 & 0.797 & 0.824 & 0.854 & 0.813 & 0.800 & 0.744 & 0.756 & 0.699 & 0.797 & 0.757 & 0.647 & 0.578 & 0.657 & 0.652 & 0.621 & 0.608 \\
\hline Hstat & 0.712 & 0.722 & 0.839 & 0.811 & 0.856 & 0.847 & 0.841 & 0.837 & 0.802 & 0.782 & 0.743 & 0.737 & 0.698 & 0.660 & 0.636 & 0.697 & 0.692 & 0.676 & 0.674 \\
\hline \multicolumn{20}{|l|}{ Slovakia } \\
\hline Lerner $_{f}$ & -0.039 & 0.170 & 0.220 & 0.220 & 0.211 & 0.288 & 0.200 & 0.129 & 0.140 & 0.198 & 0.205 & 0.229 & 0.217 & 0.214 & 0.197 & 0.296 & 0.237 & 0.228 & 0.277 \\
\hline Lerner $_{d}$ & 0.161 & 0.087 & 0.017 & -0.033 & -0.011 & 0.128 & 0.099 & 0.254 & 0.359 & 0.402 & 0.205 & 0.466 & 0.398 & 0.463 & 0.323 & 0.120 & 0.339 & 0.404 & 0.265 \\
\hline Lerner & 0.116 & 0.103 & 0.064 & 0.051 & 0.055 & 0.178 & 0.135 & 0.170 & 0.204 & 0.229 & 0.205 & 0.271 & 0.239 & 0.243 & 0.213 & 0.271 & 0.252 & 0.253 & 0.275 \\
\hline Beta $_{f}$ & -0.090 & -0.078 & -0.043 & -0.053 & 0.019 & -0.056 & -0.057 & -0.127 & -0.172 & -0.226 & -0.303 & -0.340 & -0.411 & -0.356 & -0.229 & -0.398 & -0.379 & -0.381 & -0.399 \\
\hline Beta $_{d}$ & -0.049 & -0.041 & 0.027 & 0.006 & 0.037 & -0.007 & -0.087 & -0.137 & -0.234 & -0.260 & -0.326 & -0.386 & -0.489 & -0.436 & -0.264 & -0.403 & -0.438 & -0.411 & -0.453 \\
\hline Beta & -0.058 & -0.048 & 0.011 & -0.013 & 0.031 & -0.022 & -0.077 & -0.133 & -0.190 & -0.231 & -0.306 & -0.348 & -0.420 & -0.366 & -0.233 & -0.399 & -0.387 & -0.385 & -0.407 \\
\hline Hstat $_{f}$ & 1.097 & 0.822 & 0.549 & 0.505 & 0.437 & 0.538 & 0.623 & 0.518 & 0.581 & 0.539 & 0.644 & 0.595 & 0.598 & 0.407 & 0.238 & 0.541 & 0.466 & 0.426 & 0.443 \\
\hline Hstat $_{d}$ & 0.775 & 0.655 & 0.469 & 0.429 & 0.176 & 0.261 & 0.455 & 0.448 & 0.608 & 0.505 & 0.690 & 0.613 & 0.568 & 0.419 & 0.191 & 0.658 & 0.676 & 0.446 & 0.884 \\
\hline Hstat & 0.846 & 0.688 & 0.488 & 0.454 & 0.253 & 0.348 & 0.514 & 0.498 & 0.590 & 0.541 & 0.651 & 0.598 & 0.594 & 0.408 & 0.233 & 0.558 & 0.496 & 0.429 & 0.511 \\
\hline
\end{tabular}


Table 2. Estimations of bank competition (cont.)

\begin{tabular}{|c|c|c|c|c|c|c|c|c|c|c|c|c|c|c|c|c|c|c|c|}
\hline & 1995 & 1996 & 1997 & 1998 & 1999 & 2000 & 2001 & 2002 & 2003 & 2004 & 2005 & 2006 & 2007 & 2008 & 2009 & 2010 & 2011 & 2012 & 2013 \\
\hline \multicolumn{20}{|l|}{ Slovenia } \\
\hline Lerner $_{f}$ & 0.258 & 0.369 & 0.399 & 0.336 & 0.259 & 0.338 & 0.223 & 0.268 & 0.270 & 0.288 & 0.035 & 0.184 & 0.196 & 0.200 & 0.259 & 0.300 & 0.288 & 0.284 & 0.271 \\
\hline Lerner $_{d}$ & 0.360 & 0.384 & 0.366 & 0.375 & 0.407 & 0.397 & 0.361 & 0.331 & 0.332 & 0.358 & 0.318 & 0.324 & 0.321 & 0.216 & 0.300 & 0.333 & 0.266 & 0.224 & 0.182 \\
\hline Lerner & 0.343 & 0.382 & 0.370 & 0.368 & 0.382 & 0.387 & 0.335 & 0.313 & 0.311 & 0.335 & 0.212 & 0.272 & 0.277 & 0.211 & 0.285 & 0.321 & 0.274 & 0.247 & 0.216 \\
\hline Beta $_{f}$ & -0.143 & -0.176 & -0.201 & -0.270 & -0.245 & -0.224 & -0.232 & -0.196 & -0.162 & -0.093 & 0.050 & 0.025 & 0.008 & -0.095 & -0.216 & -0.038 & -0.060 & -0.081 & -0.071 \\
\hline Beta $_{d}$ & -0.240 & -0.241 & -0.241 & -0.240 & -0.161 & -0.181 & -0.215 & -0.221 & -0.188 & -0.098 & -0.042 & 0.015 & 0.033 & -0.092 & -0.223 & -0.033 & -0.073 & -0.145 & -0.148 \\
\hline Beta & -0.224 & -0.229 & -0.237 & -0.245 & -0.175 & -0.188 & -0.219 & -0.214 & -0.179 & -0.097 & -0.008 & 0.019 & 0.024 & -0.093 & -0.220 & -0.035 & -0.068 & -0.121 & -0.119 \\
\hline Hstat $_{f}$ & 0.628 & 0.583 & 0.625 & 0.625 & 0.655 & 0.665 & 0.688 & 0.707 & 0.764 & 0.816 & 0.947 & 0.850 & 0.819 & 0.798 & 0.943 & 0.948 & 0.919 & 0.946 & 0.957 \\
\hline Hstat $_{d}$ & 0.577 & 0.605 & 0.605 & 0.632 & 0.700 & 0.700 & 0.664 & 0.663 & 0.717 & 0.788 & 0.816 & 0.812 & 0.799 & 0.793 & 0.892 & 0.868 & 0.840 & 0.861 & 0.869 \\
\hline Hstat & 0.586 & 0.601 & 0.607 & 0.631 & 0.692 & 0.694 & 0.669 & 0.676 & 0.733 & 0.797 & 0.865 & 0.826 & 0.806 & 0.795 & 0.911 & 0.898 & 0.870 & 0.893 & 0.902 \\
\hline \multicolumn{20}{|c|}{ All countries } \\
\hline Lerner $_{f}$ & 0.264 & 0.213 & 0.167 & 0.089 & 0.163 & 0.200 & 0.176 & 0.198 & 0.220 & 0.243 & 0.239 & 0.253 & 0.231 & 0.221 & 0.236 & 0.275 & 0.235 & 0.218 & 0.261 \\
\hline Lerner $_{d}$ & 0.208 & 0.198 & 0.214 & 0.060 & 0.180 & 0.167 & 0.224 & 0.219 & 0.244 & 0.281 & 0.260 & 0.296 & 0.304 & 0.191 & 0.164 & 0.122 & 0.147 & 0.165 & 0.156 \\
\hline Lerner & 0.223 & 0.202 & 0.200 & 0.072 & 0.175 & 0.182 & 0.199 & 0.205 & 0.228 & 0.256 & 0.246 & 0.267 & 0.253 & 0.212 & 0.214 & 0.223 & 0.205 & 0.201 & 0.221 \\
\hline Beta $_{f}$ & -0.279 & -0.341 & -0.394 & -0.417 & -0.381 & -0.431 & -0.472 & -0.459 & -0.464 & -0.511 & -0.527 & -0.579 & -0.621 & -0.665 & -0.559 & -0.583 & -0.619 & -0.597 & -0.578 \\
\hline Beta $_{d}$ & -0.444 & -0.442 & -0.468 & -0.455 & -0.432 & -0.467 & -0.448 & -0.479 & -0.509 & -0.543 & -0.528 & -0.535 & -0.583 & -0.582 & -0.535 & -0.540 & -0.582 & -0.583 & -0.567 \\
\hline Beta & -0.399 & -0.415 & -0.444 & -0.439 & -0.410 & -0.451 & -0.461 & -0.465 & -0.479 & -0.521 & -0.527 & -0.564 & -0.610 & -0.641 & -0.552 & -0.568 & -0.606 & -0.593 & -0.574 \\
\hline Hstat $_{f}$ & 0.834 & 0.766 & 0.750 & 0.729 & 0.729 & 0.735 & 0.710 & 0.676 & 0.700 & 0.696 & 0.689 & 0.687 & 0.673 & 0.626 & 0.560 & 0.661 & 0.640 & 0.609 & 0.602 \\
\hline Hstat $_{d}$ & 0.756 & 0.704 & 0.662 & 0.664 & 0.608 & 0.630 & 0.636 & 0.623 & 0.644 & 0.643 & 0.637 & 0.644 & 0.680 & 0.629 & 0.538 & 0.617 & 0.605 & 0.581 & 0.592 \\
\hline Hstat & 0.777 & 0.721 & 0.691 & 0.691 & 0.659 & 0.677 & 0.675 & 0.656 & 0.679 & 0.678 & 0.672 & 0.673 & 0.675 & 0.627 & 0.553 & 0.646 & 0.628 & 0.600 & 0.598 \\
\hline
\end{tabular}

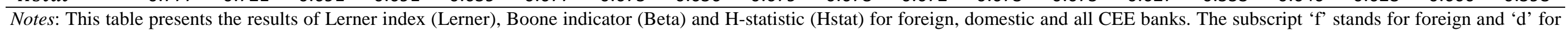
domestic banks. Measures without any subscript are for all banking institutions. 
results. As showed by Lapteacru (2014), the relationship between the Lerner index and the Hstatistic depends on the evolution of banks' revenue and production reactions to costs. He shows that in many CEE countries banks that are more competitive could have more market power, and vice versa. As for the Boone indicator, the increase in absolute value of Beta cannot be explained by the same reactions of banks. Lower marginal cost leads to continuous raise of a bank's market share not only due to increase in bank competition, as suggested by Boone (2008), but also due to a continuous consolidation process of CEE banking markets. After the financial crisis of nineties, huge financial restructuring programs were implemented with liquidation of many small insolvent banks, privatization of public banks to foreign institutions that were already, in most, on these markets (Bonin et al. 2015), and this concentration process has continued in 2000s with the merger of parent banks of CEE foreign institutions. Perhaps, this is precisely why after 2005 foreign banks gained more market share than their domestic counterparts did, being, at the same time, more efficient (Bonin et al., 2005; Fries and Taci, 2005; Havrylchyk, 2006; Zajc, 2006).

Finally, a thorough country-by-country analysis shows that during the crises of nineties the foreign banks do not do better in terms of price setting with respect to marginal cost. In Bulgaria, the Czech Republic, Latvia and Poland, they have lower market power than the domestic banks. Such difference is observed also in normal periods in Baltic countries, Slovakia and Slovenia, and only for some years in other CEE countries. In contrast, with the exception of Latvia, the foreign banks of all countries resist better during the recent financial crisis and have higher difference between the price of their products and their marginal cost. This is consistent with better performance found for foreign banks in CEE countries, which has improved during the 2000s because of better knowledge of these markets. Early Greenfield installations (Majnoni et al., 2003; Bonin et al., 2015), with more products and services and lower interest rates and prices (De Haas and Van Lelyveld, 2006; Claeys and Hainz, 2014), were changed into acquisitions of domestic entities, in order to alleviate the asymmetry of information (Van Tassel and Vishwasrao, 2007) ${ }^{3}$. Moreover, during the same period, foreign banks acquired through the privatization the formerly state-owned banks. And, besides their better performance, they gained more market shares. Their Boone indicator is in absolute value higher than that of domestic banks in Bulgaria after 2002, in Estonia and in Latvia over all period sample, and in Poland after 2001. The effect of an increasing competition is well revealed by the evolution of the H-statistic. In all countries, the revenue of foreign banks is more adjusted to changing on input prices either after a certain year, which could correspond to a huge increase in their market share, or over all period sample, as in Hungary, Lithuania and Romania.

To summarize, there is a difference in market power and competitive behaviour between foreign and domestic CEE banks. The former have lower market power and higher elasticity of their revenue to input prices. The Boone indicator also shows that foreign banks are more competitive, but after a certain year. We will now study whether there is a convergence of these three measures of bank competition and whether the convergence levels are similar across banks with different ownership profile and across countries.

\subsection{Findings of convergence levels}

The convergence levels are estimated with equation (10) after the regression of fixed effects panel model (9). As previously, when appropriate, the regressions are performed by considering the auto-correlation and the heteroscedasticity of the error term. The bank competition measures converge if and only if the solutions of equation (11) are $\left|\hat{\lambda}_{i}\right|<1$.

\footnotetext{
${ }^{3}$ As the foreign banks lack information about customers and business environment, they prefer acquire an existing customer portfolio by the acquisition of a domestic bank.
} 
Table 3. Convergence levels of Lerner index.

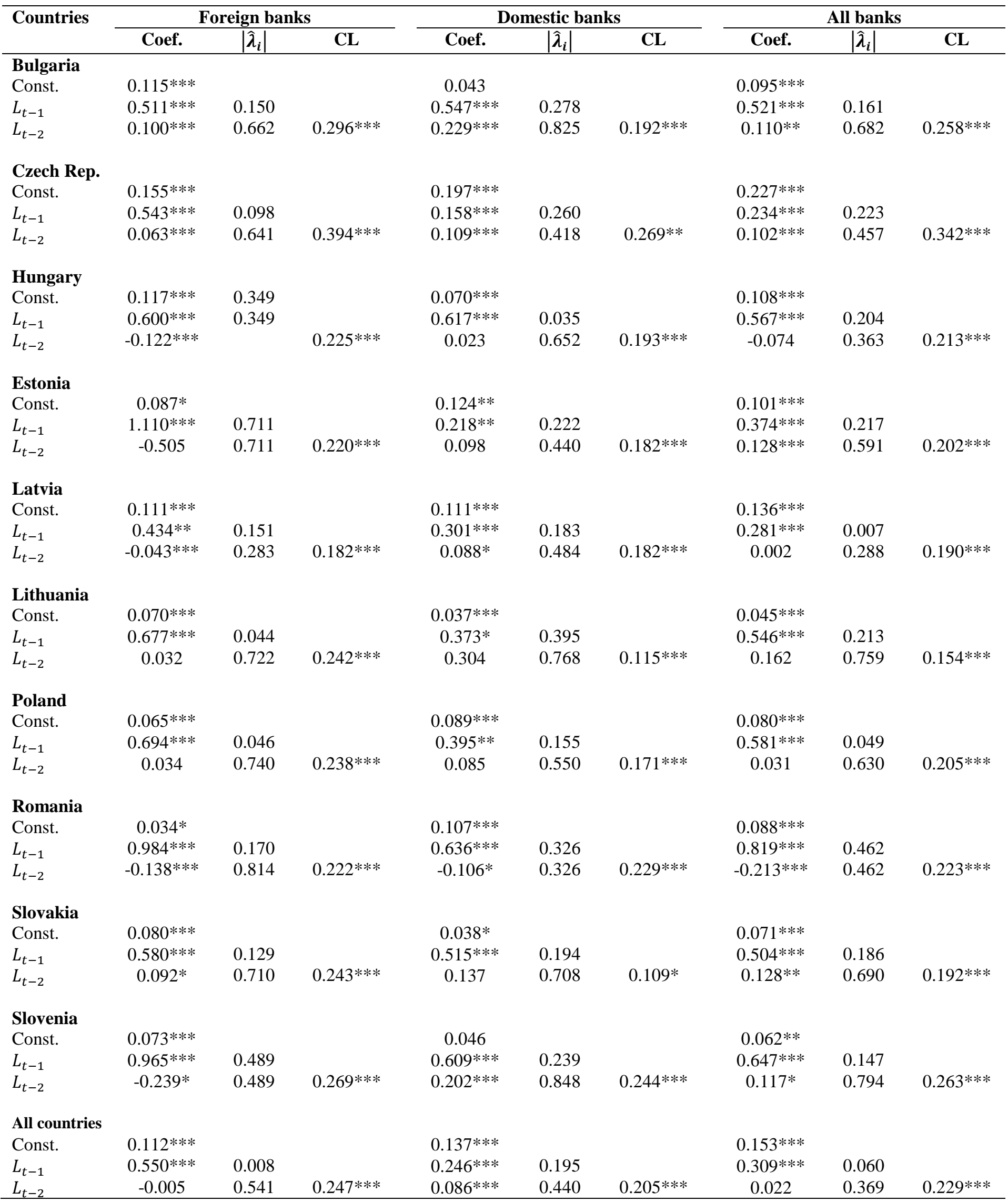

Notes: This table presents the results of convergence levels (CL) for the Lerner index, according to equations (9) and (10). The roots $\lambda_{i}$ are the solutions of equation (11) and indicate convergence if their absolute values are lower than one. ***, ** and * are statistical significances at $0.01,0.05$ and 0.10 level, respectively. 
Table 4. Convergence levels of Boone indicator.

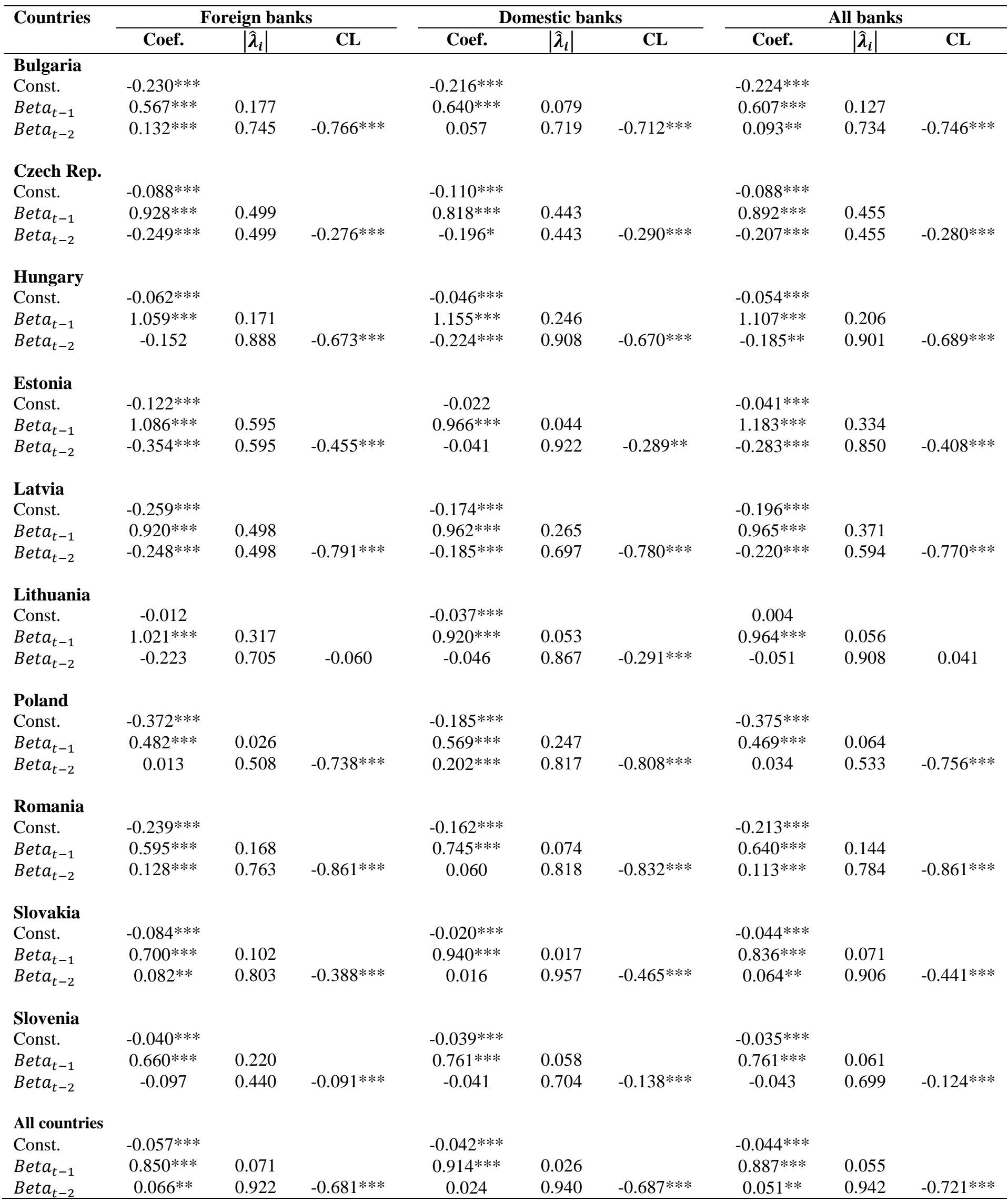

Notes: This table presents the results of convergence levels (CL) for the Boone indicator, according to equations (9) and (10). The roots $\lambda_{i}$ are the solutions of equation (11) and indicate convergence if their absolute values are lower than one. $* * *, * *$ and $*$ are statistical significances at $0.01,0.05$ and 0.10 level, respectively. 
Table 5. Convergence level of H-statistic index.

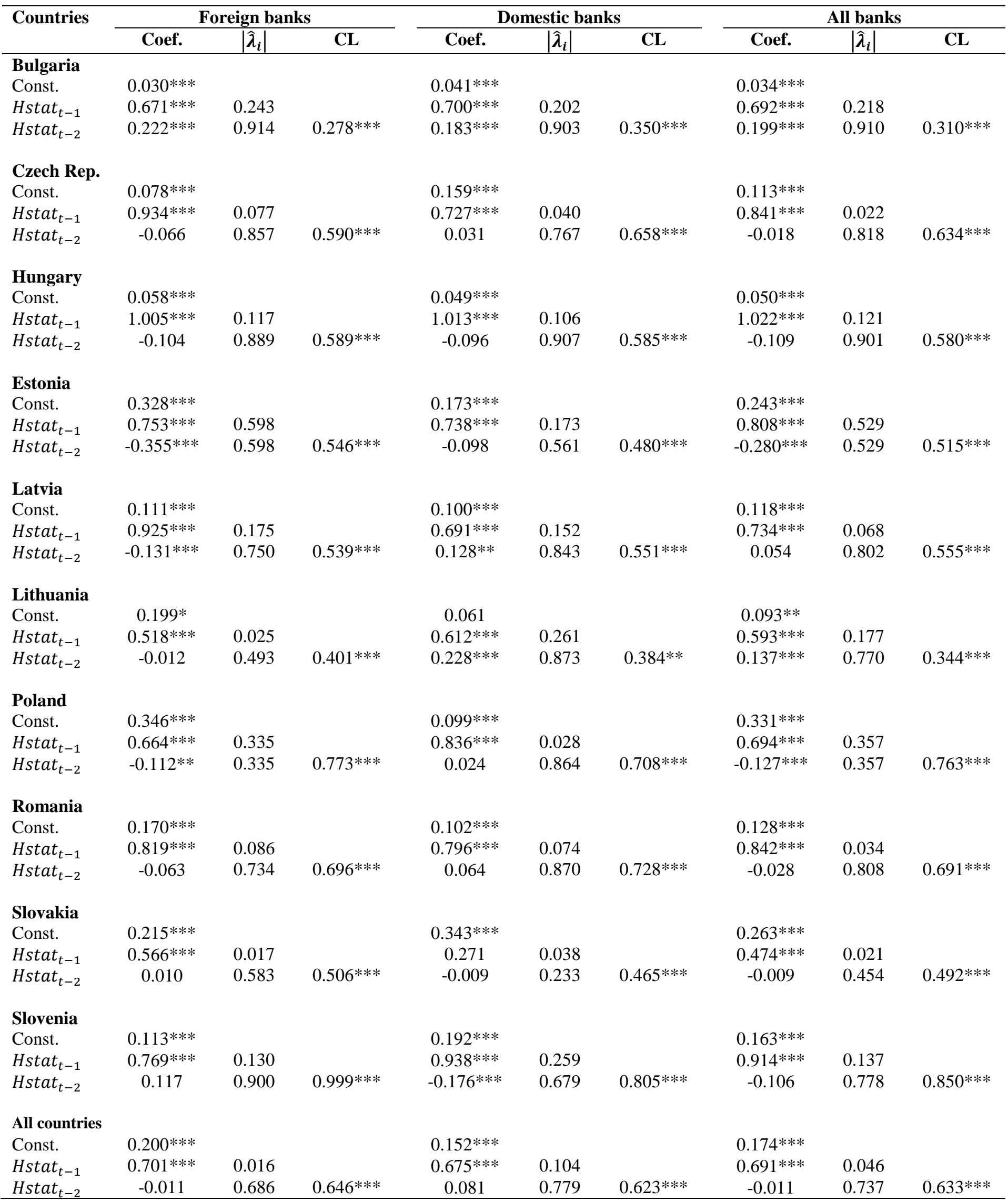

Notes: This table presents the results of convergence levels (CL) for the H-statistic, according to equations (9) and (10). The roots $\lambda_{i}$ are the solutions of equation (11) and indicate convergence if their absolute values are lower than one. $* * *, * *$ and $*$ are statistical significances at $0.01,0.05$ and 0.10 level, respectively. 
For all countries, the market power of foreign and domestic banks converges, but its convergence levels (CL) are different, including across CEE countries (see Table 3). Although their values are at levels obtained with year-by-year and country-by-country computations (see Table 2), the market power of foreign banks converges to higher levels than those of domestic institutions for all countries, with the exception of Latvia and Romania. This result is explained by a higher impact of previous levels of the Lerner index on its current value for foreign banks. More precisely, for 'all countries' the coefficient of $L_{t-1}$ is 0.550 for foreign banks and 0.246 for domestic entities. Higher values for the former are observed for almost all countries with similar levels of intercept (Const.).

Same explanations are considered for the Boone indicator (see Table 4), which, for 'all countries' regression, convergences to same levels for foreign and domestic banks around of 0.68. This is consistent with previous year-by-year findings (see Tabe2), which divide period sample in two equal sides: before 2005 when domestic banks are more competitive and after 2005 when foreign institutions are. In absolute value, it is higher for foreign banks in Bulgaria, Estonia, Latvia and Romania. Although the year-by-year estimations do never show this for Romanian banks (see Table 2), the increase rate is nevertheless higher for foreign institutions, which leads to higher convergence level.

The results for 'all countries' show slightly higher elasticity of foreign banks' revenue to input prices (see Table 5), which is also consistent with year-by-year results that show higher $\mathrm{H}$-statistic for foreign institutions over all period sample. The convergence levels vary from one country to another, with higher values for foreign banks in Estonia, Lithuania, Poland, Slovakia and Slovenia.

Overall, although convergence levels are different for foreign and domestic banks but also across countries, general trend is that foreign institutions have slightly higher market power and, at the same time, express slightly more competitive behaviour. The difference is so small that it could be explained by the statistical error. Nevertheless, the foreign banks in CEE countries can have a higher market power because their innovative products, more investment opportunities that they offer, their relative advantages in terms of risk management and the reputation of their parents can allow them to set higher price with respect to their marginal cost on a conquered banking market. At the same time, the increase in their cost is associated with much more rise in their assets than in their revenues, which, according to Lapteacru (2014), explains the divergence between the Lerner index and the Hstatistic.

Our objective is also to test the across-countries convergence. The latter is made with the nonlinear Wald statistic (eq. 14), which tests the null hypothesis of equality between previously estimated convergence levels. For the Lerner index, it cannot reject this hypothesis for domestic banks of all countries (see Table 6). All CEE domestic banks have therefore a market power that converges at a level ranging between 0.11 and 0.27 , which could be the level found previously for all countries with equations (9) and (10), that is 0.205 (see Table 3 ). The across-countries convergence test reveals two groups of countries for foreign banks: the foreign institutions of Bulgaria and the Czech Republic have a market power that converges to a same level spreading between 0.30 and 0.39 , and those of other countries to a same level ranging between 0.18 and 0.30 .

For other two measures, we observe different convergence levels across countries. In other words, there is an across-countries divergence for both foreign and domestic banks. More precisely, only the foreign banks of Bulgaria, Hungary, Latvia and Poland have a Boone indicator that converges to the same level and those of Lithuania and Slovenia to another level. The convergence levels for other countries are very different and the test rejects the hypothesis of equality between them. The Boone indicator of domestic banks is less dispersed, which allows the establishment of two large groups of countries: the Czech 
Table 6. Groups of countries with similar convergence levels of bank competition.

\begin{tabular}{|c|c|c|c|c|c|c|c|c|c|}
\hline \multirow{2}{*}{$\begin{array}{l}\text { Divergent } \\
\text { groups }\end{array}$} & \multicolumn{3}{|c|}{$\begin{array}{c}\text { Foreign banks } \\
\end{array}$} & \multicolumn{3}{|c|}{ Domestic banks } & \multicolumn{3}{|c|}{ All banks } \\
\hline & Countries & $C L$ & p-value & Countries & $C L$ & p-value & Countries & $C L$ & p-value \\
\hline & Lerner index & & & Lerner index & & & Lerner index & & \\
\hline $1^{\text {st }}$ group: & $\begin{array}{l}\text { BG, HU, ES, LV, } \\
\text { LT, PL, RO, SK, SL }\end{array}$ & $\begin{array}{l}\min =0.182 \\
\max =0.296\end{array}$ & 0.364 & All counties & $\begin{array}{l}\min =0.109 \\
\max =0.269\end{array}$ & 0.342 & $\begin{array}{l}\text { BG, HU, ES, LV, } \\
\text { LT, PL, RO, SK, SL }\end{array}$ & $\begin{array}{l}\min =0.190 \\
\max =0.263\end{array}$ & 0.646 \\
\hline $2^{\text {nd }}$ group: & $\mathrm{BG}, \mathrm{CZ}$ & $\begin{array}{l}\min =0.296 \\
\max =0.394\end{array}$ & 0.069 & & & & BG, CZ, SL & $\begin{array}{l}\min =0.258 \\
\max =0.342\end{array}$ & 0.076 \\
\hline $1^{\text {st }}$ group: & $\begin{array}{l}\text { Boone indicator } \\
\text { LT, SL }\end{array}$ & $\begin{array}{l}\min =-0.091 \\
\max =-0.060\end{array}$ & 0.751 & $\begin{array}{l}\text { Boone indicator } \\
\text { ES, SL }\end{array}$ & $\begin{array}{l}\min =-0.289 \\
\max =-0.138\end{array}$ & 0.243 & $\begin{array}{l}\text { Boone indicator } \\
\text { LT, SL }\end{array}$ & $\begin{array}{c}\min =0.041 \\
\max =-0.124\end{array}$ & 0.425 \\
\hline $2^{\text {nd }}$ group: & $\mathrm{CZ}$ & -0.276 & & CZ, ES, LT, SK & $\begin{array}{l}\min =-0.465 \\
\max =-0.289\end{array}$ & 0.863 & $\mathrm{CZ}$ & -0.280 & \\
\hline $3^{\text {rd }}$ group: & SK & -0.388 & & HU, SK & $\begin{array}{l}\min =-0.670 \\
\max =-0.465\end{array}$ & 0.328 & ES, SK & $\begin{array}{l}\min =-0.441 \\
\max =-0.408\end{array}$ & 0.360 \\
\hline $4^{\text {th }}$ group: & ES & -0.455 & & $\begin{array}{l}\text { BG, HU, LV, PL, } \\
\text { RO }\end{array}$ & $\begin{array}{l}\min =-0.832 \\
\max =-0.670\end{array}$ & 0.072 & BG, HU, LV, PL & $\begin{array}{l}\min =-0.770 \\
\max =-0.689\end{array}$ & 0.185 \\
\hline $5^{\text {th }}$ group: & BG, HU, LV, PL & $\begin{array}{l}\min =-0.791 \\
\max =-0.673\end{array}$ & 0.072 & & & & RO & -0.861 & \\
\hline $6^{\text {th }}$ group: & RO & -0.861 & & & & & & & \\
\hline
\end{tabular}


Table 6. Groups of countries with similar convergence levels of bank competition (cont.).

\begin{tabular}{|c|c|c|c|c|c|c|c|c|c|}
\hline \multirow{2}{*}{$\begin{array}{l}\text { Divergent } \\
\text { groups }\end{array}$} & \multicolumn{3}{|c|}{$\begin{array}{l}\text { Foreign banks } \\
\end{array}$} & \multicolumn{3}{|c|}{ Domestic banks } & \multicolumn{3}{|c|}{ All banks } \\
\hline & Countries & $C L$ & p-value & Countries & $C L$ & p-value & Countries & $C L$ & $p$-value \\
\hline & H-statistic & & & H-statistic & & & H-statistic & & \\
\hline $1^{\text {st }}$ group: & BG, LT & $\begin{array}{l}\min =0.278 \\
\max =0.401\end{array}$ & 0.324 & BG, ES, LT, SK & $\begin{array}{l}\min =0.350 \\
\max =0.480\end{array}$ & 0.066 & BG, LT & $\begin{array}{l}\min =0.310 \\
\max =0.344\end{array}$ & 0.758 \\
\hline $2^{\text {nd }}$ group: & $\begin{array}{l}\text { CZ, HU, ES, LV, } \\
\text { LT, SK }\end{array}$ & $\begin{array}{l}\min =0.401 \\
\max =0.590\end{array}$ & 0.154 & HU, ES, LV, SK & $\begin{array}{l}\min =0.465 \\
\max =0.585\end{array}$ & 0.077 & LT, SK & $\begin{array}{l}\min =0.344 \\
\max =0.492\end{array}$ & 0.187 \\
\hline $3^{\text {rd }}$ group: & $\mathrm{RO}$ & 0.696 & & $\mathrm{CZ}, \mathrm{HU}$ & $\begin{array}{l}\min =0.585 \\
\max =0.658\end{array}$ & 0.187 & ES, LV, SK & $\begin{array}{l}\min =0.492 \\
\max =0.555\end{array}$ & 0.267 \\
\hline $4^{\text {th }}$ group: & PL & 0.773 & & CZ, PL, RO & $\begin{array}{l}\min =0.658 \\
\max =0.728\end{array}$ & 0.593 & CZ, HU, LV & $\begin{array}{l}\min =0.555 \\
\max =0.634\end{array}$ & 0.174 \\
\hline $5^{\text {th }}$ group: & SL & 0.999 & & RO, SL & $\begin{array}{l}\min =0.728 \\
\max =0.805\end{array}$ & 0.195 & $\mathrm{CZ}, \mathrm{RO}$ & $\begin{array}{l}\min =0.634 \\
\max =0.691\end{array}$ & 0.107 \\
\hline $6^{\text {th }}$ group: & & & & & & & PL & 0.763 & \\
\hline $7^{\text {th }}$ group: & 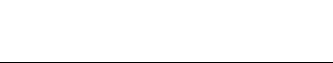 & & 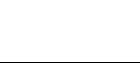 & 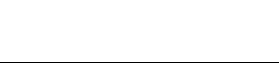 & 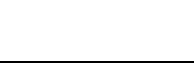 & 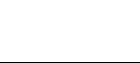 & SL & 0.850 & \\
\hline
\end{tabular}


Republic, Estonia, Lithuania and Slovakia on the one hand, and Bulgaria, Hungary, Latvia, Poland and Romania on the other. The test for the H-statistic provides so many divergent groups for both foreign and domestic banks, the former being however more dispersed.

We can conclude that, despite the bank regulatory integration and the presence of the same major foreign banks, there is no general movement toward convergence of competitive behaviour of CEE banks, neither for foreign nor for domestic institutions. The latter have a homogeneous behaviour concerning the setting of prices and interest rates with respect to marginal cost, which is a little less homogeneous for foreign banks. Even if we observed an overall divergence in convergence levels of the Boone indicator and H-statistic, it is more marked for foreign banks: same foreign banks but different strategies and price policies, concerning the gain of market shares and the revenue reaction to input prices. Their behaviour still depends heavily on local specific regulatory environment, practices and businesses.

\subsection{Findings of $\beta$-convergence and $\sigma$-convergence tests}

The last convergence test aims to uncover the way in which the convergence is happened for each country and for both types of ownership, and they are made with the regression of equations (12) and (14). Our results, displayed in Table 7, provide evidence about $\beta$ convergence and $\sigma$-convergence in bank competition with an overall examination ('All countries' side of Table 7). Indeed, the coefficients $\beta_{1}$ and $\sigma_{1}$ are, with the exception of domestic banks for the Lerner index, statistically significant for all bank competition measures and both types of ownership. Moreover, the Lerner index and the Boone indicator of foreign banks converge more rapidly than those of domestic institutions, and there is no difference for the H-statistic.

However, a country-by-country analysis provides support for faster convergence for the all competition measures of foreign banks only in Latvia, Poland and Slovenia. Hungary and Lithuania are the only countries where the convergence in competition among domestic institutions is faster with all three measures. For other countries, some competition measures converge more rapidly for foreign banks and others for domestic institutions. Consequently, even if there is a $\beta$-convergence for all countries and both ownership types, the speed of convergence diverges.

The $\sigma$-convergence test does not provide the same pattern. Even if the results bring to light the convergence of type $\sigma$ of all bank competition measures of CEE banks in overall analysis, for many countries the dispersion, especially of the Lerner index, does not diminish over time and for some of them it even increases. In the latter case, as in Estonia and Lithuania, the deviation of the yearly competition measures from their yearly across-banks average rises. Since the convergence is already proved and found above (see Tables 3-5), this signifies that the yearly across-banks average values diverge themselves from the convergence levels estimated with equations (9) and (10).

Based on these two tests, we provide support for the $\beta$-convergence in bank competition for all countries and both types of ownership. The banks with less competitiveness (less market power) in previous year have known a faster increase in their competitive behaviour (in their market power). And generally the competition measures converge more rapidly for foreign banks. Another result concerns the $\sigma$-convergence. Even if, for some countries, the test rejects this type of convergence, there is $\sigma$-convergence for all competition measures of foreign banks and only for the Boone indicator and $\mathrm{H}$-statistic of domestic institutions when we examine all countries together. 
Table 7. $\beta$-convergence and $\sigma$-convergence.

\begin{tabular}{|c|c|c|c|c|c|c|}
\hline \multirow[t]{2}{*}{ Countries } & \multicolumn{2}{|c|}{ Lerner index } & \multicolumn{2}{|c|}{ Boone indicator } & \multicolumn{2}{|c|}{ H-statistic } \\
\hline & $\beta_{1}$ & $\sigma_{1}$ & $\beta_{1}$ & $\sigma_{1}$ & $\beta_{1}$ & $\sigma_{1}$ \\
\hline \multicolumn{7}{|l|}{ Bulgaria } \\
\hline Foreign banks & $-0.516 * * *$ & -0.311 & $-0.758 * * *$ & $-0.432 * * *$ & $-0.369 * * *$ & -0.021 \\
\hline Domestic banks & $-0.743^{* * *}$ & 0.112 & $-0.752 * * *$ & $-0.370 * *$ & $-0.607 * * *$ & -0.031 \\
\hline All banks & $-0.589 * * *$ & -0.028 & $-0.687 * * *$ & $-0.432 * * *$ & $-0.381 * * *$ & $-0.065 * * *$ \\
\hline \multicolumn{7}{|l|}{ Czech Rep. } \\
\hline Foreign banks & $-0.972 * * *$ & -1.026 & $-0.694 * * *$ & -0.068 & $-0.339 * * *$ & $-0.256 * * *$ \\
\hline Domestic banks & $-0.795 * * *$ & $-2.155 *$ & $-0.774 * * *$ & -0.030 & $-0.498 * * *$ & $-0.841 * * *$ \\
\hline All banks & $-0.911 * * *$ & $-1.452 * * *$ & $-0.639 * * *$ & $-0.094 * *$ & $-0.404 * * *$ & $-0.299 * * *$ \\
\hline \multicolumn{7}{|l|}{ Hungary } \\
\hline Foreign banks & $-0.885 * *$ & 0.179* & $-0.615^{* * *}$ & -0.005 & $-0.461 * * *$ & -0.002 \\
\hline Domestic banks & $-1.045^{* * *}$ & $-1.996 * * *$ & $-0.855 * * *$ & -0.029 & $-0.767 * * *$ & -0.029 \\
\hline All banks & $-0.921^{* * *}$ & -0.057 & $-0.643^{* * *}$ & -0.014 & $-0.499 * * *$ & 0.029 \\
\hline \multicolumn{7}{|l|}{ Estonia } \\
\hline Foreign banks & $-0.588 * *$ & $1.416^{* * *}$ & $-0.680 * * *$ & $0.098 * * *$ & $-1.007 * * *$ & $0.805 * * *$ \\
\hline Domestic banks & $-0.999 * * *$ & -0.343 & $-0.996 * * *$ & 0.014 & $-0.723 * * *$ & -0.008 \\
\hline All banks & $-0.867 * * *$ & $0.499 * *$ & $-0.953 * * *$ & $0.045^{* * *}$ & $-0.589 * * *$ & 0.138 \\
\hline \multicolumn{7}{|l|}{ Latvia } \\
\hline Foreign banks & $-0.991 * * *$ & $-2.639 *$ & $-0.860 * * *$ & -0.015 & $-0.767 * * *$ & 0.107 \\
\hline Domestic banks & $-0.682 * * *$ & 0.716 & $-0.648 * * *$ & -0.010 & $-0.479 * * *$ & 0.062 \\
\hline All banks & $-0.796 * * *$ & -0.700 & $-0.540 * * *$ & $-0.047 * *$ & $-0.500 * * *$ & 0.069 \\
\hline \multicolumn{7}{|l|}{ Lithuania } \\
\hline Foreign banks & $-0.848 * * *$ & -0.559 & $-0.333 * *$ & $0.923 * * *$ & -0.257 & $1.255^{* * *}$ \\
\hline Domestic banks & $-0.943^{* * *}$ & -0.292 & $-0.521 * * *$ & -0.160 & $-0.699 * * *$ & $0.747 *$ \\
\hline All banks & $-0.882 * * *$ & $-0.260 *$ & $-0.448 * * *$ & $0.312 * *$ & $-0.404 * * *$ & 0.124 \\
\hline \multicolumn{7}{|l|}{ Poland } \\
\hline Foreign banks & $-0.664 * * *$ & -0.026 & $-0.661 * * *$ & -0.021 & $-0.485^{* * *}$ & -0.085 \\
\hline Domestic banks & $-0.501 * * *$ & -0.012 & $-0.529 * * *$ & $-0.471 * * *$ & $-0.269 * * *$ & -0.039 \\
\hline All banks & $-0.552^{* * *}$ & 0.017 & $-0.570 * * *$ & $-0.193 * * *$ & $-0.359 * * *$ & $-0.109 * * *$ \\
\hline \multicolumn{7}{|l|}{ Romania } \\
\hline Foreign banks & $-0.453^{* * *}$ & -0.040 & $-0.389 * * *$ & $-0.292 * * *$ & $-0.516 * * *$ & $-0.339 * * *$ \\
\hline Domestic banks & $-0.197 * *$ & -0.057 & $-0.397 * * *$ & $-0.241 * * *$ & $-0.424 * * *$ & -0.029 \\
\hline All banks & $-0.336 * * *$ & 0.010 & $-0.362 * * *$ & $-0.253 * * *$ & $-0.477 * * *$ & $-0.289 * * *$ \\
\hline \multicolumn{7}{|l|}{ Slovakia } \\
\hline Foreign banks & $-0.615^{* * *}$ & $-0.635 * * *$ & $-0.672 * * *$ & $-0.220 * * *$ & $-0.437 * * *$ & $-0.331 * *$ \\
\hline Domestic banks & $-0.881 * * *$ & -0.973 & $-0.675^{* * *}$ & $-0.551 * * *$ & $-0.663 * * *$ & -1.042 \\
\hline All banks & $-0.631 * * *$ & $-0.599 * *$ & $-0.641 * * *$ & $-0.219 * * *$ & $-0.573 * * *$ & $-0.331 * *$ \\
\hline \multicolumn{7}{|l|}{ Slovenia } \\
\hline Foreign banks & $-0.496 * * *$ & -0.051 & $-0.451 * * *$ & $-0.158 *$ & $-0.485^{* * *}$ & $0.220 * *$ \\
\hline Domestic banks & $-0.391 * * *$ & 0.095 & $-0.244 * * *$ & $-0.316 * * *$ & $-0.391 * * *$ & $-0.194 * *$ \\
\hline All banks & $-0.406 * * *$ & 0.105 & $-0.253 * * *$ & $-0.278 * * *$ & $-0.392 * * *$ & $-0.107 *$ \\
\hline \multicolumn{7}{|l|}{ All countries } \\
\hline Foreign banks & $-0.889 * * *$ & $-0.301 * *$ & $-0.351 * * *$ & $-0.099 * * *$ & $-0.541 * * *$ & $-0.058 *$ \\
\hline Domestic banks & $-0.771 * * *$ & -0.204 & $-0.297 * * *$ & $-0.253^{* * *}$ & $-0.577 * * *$ & $-0.089 *$ \\
\hline All banks & $-0.817 * * *$ & $-0.263 * * *$ & $-0.252 * * *$ & $-0.162 * * *$ & $-0.543 * * *$ & $-0.106 * * *$ \\
\hline
\end{tabular}




\section{Conclusion}

Even if the CEE countries followed different ways to join the European Union, all of them adopted the same liberalizing banking reforms with the view to join the European banking market. Therefore, we can wonder whether all these efforts led to the convergence of competitive behaviour of CEE banks, because only within an integrated banking market banks should price identically their products and services. Thus, we have examined the within-country convergence of bank competition, that is, the within-country banking integration, and the across-countries convergence, that is, the CEE banking integration.

This issue is especially important for CEE economies where the presence of foreign banks increased continuously, reaching for some countries more than $90 \%$ of their banking market. As members of same large European banking groups, these institutions are supposed to increase the bank competition and, at the same time, to enhance the convergence of competitive behaviour of CEE banks. To determine the difference in bank competitiveness and its convergence between foreign and domestic banks, we have firstly estimated the three most used bank competition measures in banking literature, which are the Lerner index, the Boone indicator and the $\mathrm{H}$-statistic. We have then applied innovative convergence tests.

We find that the Lerner index, the Boone indicator and the H-statistic show different trends, which are observed for both foreign and domestic banks. This does not mean contradictory results, because these measures are conceptually very different and each of them provides specific information about the competitiveness of banks. There is however some difference between foreign and domestic institutions. The former have lower market power until the recent financial crisis to which they resist better. They also have an enhanced competitive behaviour after 2004 with the Boone indicator and over all period with the $\mathrm{H}$ statistic. One has to mention that these results are very different across CEE countries.

Consequently, even though all competition measures converge for all countries and for both types of ownership, the convergence levels are different. Therefore, only the market power of CEE domestic banks converges to the same level. The lack of convergence across CEE countries of the Boone indicator and of the H-statistic is confirmed for both foreign and domestic banks. However, the foreign institutions show for all three measures more dispersed convergence groups. Despite the efforts for banking market integration and the presence of the same major foreign banks, there is no general movement toward convergence of competitive behaviour of CEE banks, neither for foreign nor for domestic institutions.

Finally, $\beta$-convergence test supports the view that banks with less competitiveness (less market power) in previous year have known a faster increase in their competitive behaviour (in their market power) and that the competition measures converge more rapidly for foreign banks. Despite the rejection by many countries of the $\sigma$-convergence test, the overall test confirms the reduction of the deviation of competition measures from their yearly acrossbanks average value, with different speeds for foreign and domestic banks. Consequently, bank ownership matters in the convergence of bank competition. Foreign banks have not only an enhanced competitive behaviour but also more dispersed convergence levels. Further research is however needed in order to determine the specific role of foreign banks in the integration of CEE banking markets from the point of view of banks' competitive behaviour. It could focus, in more details, on the impact of foreign ownership on the convergence process: an accelerating effect or, on the contrary, a slowing effect. 


\section{References}

Agoraki, M.-E., Delis, M. and Pasiouras, F. (2011). 'Regulations, competition and bank risktaking in transition countries', Journal of Financial Stability, 7, pp. 38-48.

Barro, R. and Sala-I-Martin, X. (1991). 'Convergence across states and regions', Brookings Papers on Economic Activity, 1, pp. 107-182.

Berger, A., Klapper, L. and Turk-Ariss, R. (2009). 'Bank competition and financial stability', Journal of Financial Services Research, 21, pp. 849-870.

Bikker, J. A. and Haaf, K. (2002). 'Competition, concentration and their relationship: an empirical analysis of the banking industry', Journal of Banking and Finance, 26, pp. 21912214.

Bikker, J. A. and van Leuvensteijn, M. (2008). 'Competition and efficiency in the Dutch life insurance industry’, Applied Economics, 40, pp. 2063-2084.

Bonin, J., Hasan, I. and Wachtel, P. (2005). 'Bank performance, efficiency and ownership in transition countries', Journal of Banking and Finance, 29, pp. 31-53.

Bonin, J., Hasan, I. and Wachtel, P. (2015). 'Banking in Transition Countries' In: Berger, A., Molyneux, Ph., Wilson, J., The Oxford Handbook of Banking, second edition. Oxford University Press, United Kingdom, pp. 963-983.

Buch, C. M., Koch, C. T. and Koetter, M. (2013). 'Do banks benefit from internationalization? Revisiting the market-power risk nexus', Review of Finance, 17, pp. 1401-1435.

Boone, J. (2008). 'A new way to measure competition', The Economic Journal, 118, pp. 12451261.

Carbó, S., Humphrey, D., Maudos, J. and Molyneux, Ph. (2009). 'Cross-country comparisons of competition and pricing power in European banking', Journal of International Money and Finance, 28, pp. 115-134.

Claeys, S. and Hainz, C. (2014). 'Modes of Foreign Bank Entry and Effects on Lending Rates: Theory and Evidence', Journal of Comparative Economics, 42, pp. 160-177.

Coccorese, P. (2004). 'Banking competition and macroeconomic conditions: a disaggregate analysis', Journal of International Financial Markets, Institutions and Money, 14, pp. 203219.

De Bandt, O. and Davis, E. (2000). 'Competition, contestability and market structure in European banking sector on the eve of EMU', Journal of Banking and Finance, 24, pp. 1045-1066.

De Haas, R. and Van Lelyveld, I. (2006). 'Foreign banks and credit stability in Central and Eastern Europe. A panel data analysis', Journal of Banking and Finance, 30, pp. 1927-1952.

Degryse, H., Kim, M. and Ongena, S. (2009). 'Microeconometrics of Banking: Methods, Applications, and Results', Oxford University Press, USA.

Delis, M.D. (2012). 'Bank competition, financial reform, and institutions: the importance of being developed', Journal of Development Economics, 97, pp. 450-465.

Demirgüç-Kunt, A., Levine, R. and Min, H. G. (1998). 'Foreign Banks: Efficiency, Stability and Growth'. In: The Implication of Globalization of World Financial Markets. Seoul, Korea.

Detregiache, E. and Gupta, P. (2004). 'Foreign Banks in Emerging Market Crises: Evidence from Malaysia’, IMF Working Paper 04/129.

Dracos, K. and Konstantinou, P. (2005). 'Competition and Contestability in transition banking: an empirical analysis', South-Eastern Europe Journal of Economics, 2, pp. 183-209.

Fernández de Guevara, J., Maudos, J. and Pérez, F. (2007). 'Integration and competition in the European financial markets', Journal of International Money and Finance, 26, pp. 26-45.

Fries, S. and Taci, A. (2005). 'Cost efficiency of bank in transition: Evidence from 289 banks and 15 post-communist countries', Journal of Banking and Finance, 29, pp. 55-81.

Fungacova, Z. and Weill, L. (2013). 'Does competition influence bank failures? Evidence from 
Russia', Economics of Transition, 21, pp. 301-322.

Gelos, R. and Roldós, J. (2002). 'Consolidation and Market Structure in Emerging Market Banking Systems', IMF Working paper 02/186.

Greene, W. H. (2012). 'Econometric Analysis'. Seventh edition. International edition. Pearson.

Havrylchyk, O. (2006). 'Efficiency of the Polish banking industry: Foreign versus domestic banks', Journal of Banking and Finance, 30, pp. 1975-1996.

Hondroyiannis G., Lolos S. and Papapetrou E. (1999). 'Assessing competitive conditions in the Greek banking system', Journal of International Financial Markets, Institutions and Money, 9, pp. 377-391.

Lapteacru, I. and Nys, E. (2011). 'Impact of competition on bank efficiency: the case of Eastern and Central Europe', Revue Economique, 62, pp. 313-330.

Lapteacru, I. (2014). 'Do more competitive banks have less market power? The evidence from Central and Eastern Europe', Journal of International Money and Finance, 46, pp. 41-60.

Leon, F. (2015). 'Does bank competition alleviate credit constraints in developing countries?', Journal of Banking and Finance, 57, pp. 130-142.

Love, I. and Martinez Peria, M. (2015). 'How bank competition affects firms' access to finance', World Bank Economic Review, 29, pp. 413-448.

Majnoni, G., Shankar, R. and Várhegyi, E. (2003). 'The Dynamics of Foreign Bank Ownership: Evidence from Hungary’, World Bank working paper 3114.

Mamatzakis, E., Staikouras, C. and Koutsomanoli-Fillipaki, N. (2005). 'Competition and concentration in the banking sector of the South Eastern European region', Emerging Markets Review, 6, pp. 192-209.

Maudos, J. and Fernández de Guevara, J. (2007). 'The cost of market power in banking: Social welfare loss vs. cost inefficiency’, Journal of Banking and Finance, 31, pp. 2103-2125.

Molyneux, P., Lloyd-Williams, D.M. and Thornton, J. (1994). 'Competitive conditions in European banking', Journal of Banking and Finance, 18, pp. 445-459.

Quah, D., (1996). 'Empirics for economic growth and convergence', European Economic Review, 40, pp. 1353-1376.

Panzar, J. and Rosse, J. (1987). 'Testing for “monopoly” equilibrium', Journal of Industrial Economics, 35, pp. 443-456.

Pruteanu-Podpiera, A., Weill, L. and Schobert, F. (2008). 'Banking competition and cost efficiency: a micro-data analysis on the Czech banking industry', Comparative Economic Studies, 50, pp. 253-273.

Solís, L. and Maudos, J. (2008). 'The social costs of bank market power: Evidence from Mexico', Journal of Comparative Economics, 36, pp. 467-488.

Tabak, B.M., Fazio, D.M. and Cajueiro, D.O. (2012). 'The relationship between banking market competition and risk-taking: do size and capitalization matter?', Journal of Banking and Finance, 36, pp. 3366-3381.

Van Leuvensteijn, M., Bikker, J. A., van Rixtel, A. and Kok Sørensen, C. (2011). 'A new approach to measuring competition in the loan markets of the euro area', Applied Economics, 43, pp. 3155-3167.

Van Tassel, E. and Vishwasrao, S. (2007). 'Asymmetric information and the mode of entry in foreign credit markets', Journal of Banking and Finance, 31, pp. 3742-3760.

Zajc, P. (2006). 'A comparative study of bank efficiency in central and eastern Europe: The role of foreign ownership', International Finance Review, 6, pp. 117-156.

Weill, L. (2009). 'Convergence in banking efficiency across European countries', Journal of International Financial Markets, Institutions and Money, 19, pp. 818-833.

Weill, L. (2013). 'Bank competition in the EU: How has it evolved?', Journal of International Financial Markets, Institutions and Money, 26, pp. 100-112. 


\section{RECENT LAREFI WORKINg PAPERS}

\section{For earlier LAREFI Working Papers, please go to http://lare-efi.u-bordeaux4.fr}

\section{All Discussion Papers can be downloaded free of charge}

CR16-EFI05 Lapteacru, I., "On the consistency of the Z-score to measure the bank risk"

CR16-EFI04 Lapteacru, I., "Income and funding structures, banking regulation and bank risk-taking : The role of ownership in Central and Eastern European banks"

CR16-EFI03 Humblot, T., "Distance et accès au crédit sous Bâle III"

CR16-EFI02 Berthoumieu, J. and V. Lamani, "Vertical Differentiation, Uncertainty, Product R\&D and Policy Instruments in a North-South Duopoly"

CR16-EFI01 Raffestin, L., "Foreign exchange investment rules and endogenous currency crashes" CR15-EFI05 Berthoumieu,J., "Technology Diffusion via Patent Collaborations : The Case of European Integration"

CR15-EFI04 Bouet, A. and A-G. Vaubourg, "Financial Constraints and International Trade with Endogenous Mode of Competition"

CR15-EFI03 Lahet, D. and A-G. Vaubourg, "Banks' shareholding in multilateral trading facilities : A twosided market perspective"

CR15-EFI02 Berthoumieu, J., "Policy Instruments, Patents and International Technology Diffusion in a North-South Duopoly"

CR15-EFI01 Dupuy, L., "International trade and structural change : a dynamic model of weak sustainability"

CR14-EFI06 Humblot, T., "Basel III and SMEs' access to bank credit : An empirical assessment"

CR14-EFI05 Nicet-Chenaf, D., Rougier, E., "Source and host country volatility and FDI : A gravity analysis of European investment to Middle East and North Africa"

CR14-EFI/04 Djigbenou, M-L., "Determinants of Global Liquidity Dynamics:a FAVAR approach"

CR14-EFI/03 Vaubourg, A-G., "Finance and international trade : A review of the literature"

CR14-EFI/02 Sangaré, I., "Chocs extérieurs et régimes monétaires en Asie du Sud-Est : une analyse DSGE"

CR14-EFI/01 Lacoue-Labarthe, D., "In Search of the Banking Regulator amid U.S. Financial Reforms of the 1930s" 